\title{
Okul Öncesi Öğretmenlerinin Mesleğe Yabancılaşma Düzeylerinin Bazı Değişkenler Açısından Íncelenmesi
}

\author{
Yrd. Doç. Dr. Latife KABAKLI-ÇİMEN \\ İstanbul Sabahattin Zaim Üniversitesi, Eğitim Fakültesi, Temel Eğitim Bölümü, \\ İstanbul / Türkiye, ORCID: 0000-0002-4973-3630
}

\section{$\ddot{\mathbf{O} z}$}

$\mathrm{Bu}$ araştırma resmî ve özel okullarda görev yapan okul öncesi öğretmenlerinin işe yabancılaşma düzeylerini ve bunları etkileyen değişkenleri belirlemek amacıyla yapılmıştır. Araştırma betimsel tarama modelinde gerçekleştirilmiştir. Araştırmaya 60 resmî ve özel okulda görev yapan 288 okul öncesi öğretmeni katılmıştır. Araştırmanın verileri "Kişisel Bilgi Formu” ve "Okul Öncesi Öğretmenlerinin İşe Yabancılaşma Ölçeği” kullanılarak elde edilmiş ve SPSS programında çözümlenmiştir. Araştırma sonucunda okul öncesi öğretmenlerinin mesleğe yabancılaşma düzeylerinin genel olarak düşük düzeyde, Güçsüzlük Duygusu ve Normsuzluk boyutlarında kısmen yüksek; Anlamsızlık Duygusu boyutunda ise en düşük düzeyde olduğu belirlenmiştir. Araştırma sonucunda okul öncesi öğretmenlerinin mesleğe yabancilaşma düzeylerinin; haftalık çalışma saatine göre, Normsuzluk alt boyutunda, eğitim kurumu türü değişkenine göre; ölçek geneli ile Kendine Yabancılaşma ve Normsuzluk alt boyutlarında, mesleği isteyerek seçip seçmeme değişkenine göre; ölçek geneli ile Anlamsızlık Duygusu ve Yalıtılmışlık Duygusu alt boyutunda anlamlı farklılık bulunmuştur. Sınıfında kaynaştırma öğrencisi olup olmaması değişkenine göre; Kendine Yabancılaşma ve Normsuzluk alt boyutlarında, mezun olunan bölüm değişkenine göre; Kendine Yabancılaşma ve Normsuzluk alt boyutlarında, iş

* Sorumlu Yazar. Tel: +90 2126929629 E-posta: latife.cimen@izu.edu.tr

CC 2018 Kalem Eğitim ve Sağlık Hizmetleri Vakfı. Bütün Hakları Saklıdır. ISSN: 2146-5606 
yerindeki arkadaşlık ilişkileri değişkenine göre ise ölçek geneli ile Anlamsızlık Duygusu, Yalıtılmışlık Duygusu, Güçsüzlük Duygusu ve Normsuzluk alt boyutlarında anlamlı farklılık saptanmıştır. Okul öncesi öğretmenlerinin mesleğe yabancılaşma düzeylerinin medeni durum, yaş, hizmet süresi, sınıf mevcudu, kurum imkânları, algılanan gelir düzeyi değişkenlerine göre anlamlı bir farkl1lık göstermediği belirlenmiştir.

Anahtar Kelimeler: Yabancılaşma; İşe yabancılaşma; Okul öncesi öğretmenlerinin işe yabancılaşmasi; Eğitimde yabancılaşma.

\title{
An Examination of the Levels of Occupational Alienation of Pre-school Teachers from Their Profession in Terms of Some Variables
}

\begin{abstract}
This study, which was carried out for the purpose of determining the occupational alienation levels (sense of insignificance, sense of isolation, self-alienation, powerlessness, normlessness) of pre-school teachers working at state and private schools and the variables affecting them, was conducted in the relational screening model. 288 pre-school teachers working at 60 state and private schools participated in the study by way of the unbiased sampling method. The data of the study were collected by using the Occupational Alienation of Pre-school Teachers Scale. The data obtained were analyzed in the SPSS program. One of the results of the study is that the occupational alienation levels of preschool teachers were found to be at a low level in general, partially high in the Sense of Powerlessness and Normlessness dimensions and at the lowest level in the sense of insignificance dimension. Another result is that significant differences were found in the occupational alienation statuses of pre-school teachers, in the normlessness sub-dimension according to weekly working hours, in the overall scale and self-alienation and normlessness sub-dimensions according to the variable of the type of educational institution, in the overall scale and sense of insignificance and isolation sub-dimensions according to the variable of choosing the occupation with one's own will. Significant differences
\end{abstract}


were determined in the self-alienation and normlessness sub-dimensions according to the variable whether there was an inclusive student in the class, in the self-alienation and normlessness sub-dimensions according to the variable of the department graduated from, in the overall scale and the sense of insignificance, sense of isolation, powerlessness and normlessness sub-dimensions according to the friendship relationships at workplace variable. It was determined that the occupational alienation levels of pre-school teachers did not demonstrate a significant difference in regard to the variables of marital status, age, the term of service, classroom size, institutional facilities, and the perceived income level.

Keywords: Alienation; Occupational alienation; Alienation of preschool teachers; Alienation in education.

\section{Extended Summary}

\section{Purpose}

This study was carried out for the purpose of determining the levels of professional alienation (the sense of meaninglessness, the sense of isolation, self-estrangement, powerlessness, normlessness) of pre-school teachers working at public and private schools, and the variables that affect them.

Alienation was classified in five main dimensions by Seeman (1967): meaninglessness, powerlessness, normlessness, isolation and self-estrangement.

According to Elma (2003), alienation is that the employee cannot get satisfaction from the relationships established at the workplace, finds one's job meaningless, feels lonely, incompetent and powerless, loses hopes for the future and perceives oneself as a simple part of the system. The alienation of teachers from their work prevents their productiveness, being a role model to their students and the society, developing themselves in professional terms, contributing to social development, the effectiveness of the educational process, the efficiency of teaching service, and working in cooperation with the school management and other teachers There are many reasons why teachers become alienated from their profession. These are the bureaucratic structure at schools, intensive and changing curriculum, rapidly changing technological material, crowded classes, unfunctional loads of information that are of no use for daily life, and excluding students and teachers from educational decisionmaking processes. 
Upon examining the relevant literature, there are studies on the alienation of teachers from different teaching levels from the profession (Açıkel, 2013; Aslan, 2008; Celep, 2008; Çalışır, 2006; Elma, 2003; Emir, 2012; Erjem, 2005; Kesik and Cömert, 2014; Kılçık, 2011; Kösterelioğlu, 2011; Temel, 2010). Nevertheless, there are limited studies of Kıhrı (2013) and Mahmutyazıcıoğlu (2015) on the alienation of pre-school teachers from their profession. It is believed that this study that is conducted in order to determine the levels of alienation of pre-school teachers from the profession will contribute to the development of pre-school teachers and educational institutions.

\section{Method}

In this study, the findings were obtained using the descriptive screening model among quantitative research methods. 288 pre-school teachers working at 60 public and private schools in Küçükçekmece district on the European side and Ümraniye district on the Asian side of Istanbul and selected with the random sampling method participated in the study.

The research data were obtained by applying the personal information form and the scale of alienation of pre-school teachers from their profession by the researcher. The reliability coefficients of the scale are .967 for the Cronbach's Alpha Sense of Meaninglessness, .963 for the Sense of Isolation, .912 for Self-Estrangement, .915 for the Sense of Powerlessness, .823 for Normlessness, and .966 for the total scale.

\section{Result}

According to the research results, it was determined that the alienation levels of pre-school teachers from the profession are "low" with $\bar{x}=2.27$ when compared to the general average, the dimensions of the sense of powerlessness and normlessness are partially high, and the sense of meaninglessness is at the lowest level.

The overall scale and sub-dimensions of the alienation of pre-school teachers from the profession do not vary significantly by the variables of gender, marital status, age, duration of service, class size, institutional facilities, the number of children and perceived levels of income ( $p>0.05)$.

The alienation of pre-school teachers from the profession by the variable of weekly working hours varies significantly only in the normlessness subdimension $[\mathrm{t}=2.65, p<.05]$. Accordingly, the arithmetic mean of the partici- 
pants whose weekly working hours are 20-30 $(\bar{x}=2.96)$ is higher than the arithmetic mean $(\bar{x}=2.74)$ of the participants with weekly working hours between 31 and 40 hours.

It was determined that the self-estrangement $[\mathrm{t}=3.79, p<.05]$ and normlessness $[\mathrm{t}=2.65, p<.05]$ levels of teachers working at state / public preschool education institutions are higher when compared to those of teachers working at private pre-school education institutions.

It was determined that the level of alienation, meaninglessness, and isolation of the participants who have chosen the profession willingly is lower than that of those who have chosen the profession unwillingly.

A significant difference was determined in the sub-dimensions of selfestrangement [ $\mathrm{t}=2.900, p<.05]$ and normlessness $[\mathrm{t}=2.346, p<.05]$ according to whether pre-school teachers have inclusive students.

A significant difference was determined according to the variable of the relations of pre-school teachers with managers in the overall scale $(\mathrm{F}=17.765$, $p<.05)$, the sense of meaninglessness $(\mathrm{F}=12.127, p<.05)$, the sense of isolation $(\mathrm{F}=16.840, p<.05)$, self-estrangement $(\mathrm{F}=5.836, p<.05)$, powerlessness $(\mathrm{F}=17.955, p<.05)$ and normlessness $(\mathrm{F}=13.478, p<.05)$ sub-dimensions. It is observed that teachers with the low and medium level of relations with their managers experience a higher level of meaninglessness, isolation, powerlessness, and normlessness when compared to teachers with strong relations with their managers $(p<.05)$. Teachers with the medium level of relations with their managers experience a higher level of self-estrangement when compared to teachers with strong relations with their managers $(p<.05)$. Teachers with the low and medium level of relations with their managers experience a higher level of alienation when compared to teachers with strong relations with their managers $(p<.05)$.

A significant difference was determined in the alienation of pre-school teachers from their profession in the sub-dimensions of self-estrangement $[\bar{x}=11.01, p<.05]$ and normlessness $[\bar{x}=26.48, p<.05]$ by the variable of educational level. As a result of the Mann-Whitney U Test conducted for the determination of differences, while an increase was generally observed in the level of self-estrangement as the level of education increased, the self-estrangement levels of only those with associate degree were determined to be significantly lower when compared to those with master's degree. As a result 
of the Mann-Whitney U Test conducted, it is observed that the level of normlessness increases in general as the level of education increases. It was determined that the normlessness levels of high school graduates and associate degree holders were significantly lower when compared to those of bachelor's and master's degree holders.

A significant difference was observed in the self-estrangement $[\bar{x}=7.98$, $p<.05]$ and normlessness $[\bar{x}=26.12, p<.05]$ sub-dimensions of the alienation of pre-school teachers from the profession by the variable of graduation. As a result of the Mann-Whitney U Test conducted for the determination of differences, it was determined that the self-estrangement and normlessness levels of the graduates of pre-school teaching were significantly higher than those of the graduates of child development.

A significant difference was determined in the overall scale $[\bar{x}=26.19$, $p<.05]$ and the sub-dimensions of the sense of meaninglessness $[\bar{x}=26.38$, $p<.05]$, the sense of isolation $[\bar{x}=38.14, p<.05]$, powerlessness $[\bar{x}=24.53$, $p<.05]$ and normlessness in the alienation of pre-school teachers from the profession by the variable of friendship relationships. As a result of the MannWhitney U Test conducted for the determination of differences, it was determined that the levels of alienation, meaninglessness, isolation, powerlessness, and normlessness of the participants decreased significantly as the level of the relationship with their colleagues increased.

\section{Conclusion}

The results of this study show that the levels of alienation of pre-school teachers from the profession are generally low. Many studies (Akpolat ve Oğuz, 2015; Aksu and Güneri, 2011; Aydın, 2015; Büyükyılmaz, 2007; Celep, 2008; Çalışır, 2006; Elma, 2003; Emir, 2012; Erdem, 2014; Erjem, 2005; Eryılmaz and Burgaz, 2011; Gür, 2009; Kılçık, 2011; Kösterelioğlu, 2011; Şimşek, Balay ve Şimşek, 2012; Yıldız, 2016; Yıldız, Akgün ve Y1ldız, 2013; Y1lmaz and Sarpkaya, 2009; Yorulmaz, Altınkurt ve Y1lmaz, 2015; Temel, 2010) show that the alienation levels of teachers from their profession are low and support our findings.

According to the results obtained from this study, teachers working for 20-30 hours a week experience the sense of normlessness more when compared to teachers who work for 31-40 hours a week. The study of Halaçoğlu (2008) supports our results. 
It was determined that pre-school teachers working at public pre-school institutions experience more alienation from the profession when compared to pre-school teachers working at private schools. The studies of Kılıç (2009), Eryılmaz (2010), Kınık (2010), Açıkel (2013), Korkmaz (2014), Mahmutyazıcıoğlu (2015), Oksay and Durmaz (2016) support our study.

According to the research results, it has been determined that the level of alienation, meaninglessness, and isolation of pre-school teachers who have chosen their profession willingly is lower than that of teachers who have chosen their profession unwillingly. The study of Kilıç (2009) also shows parallelism with the results of this study.

The results of this study show that the levels of alienation of pre-school teachers from their profession vary significantly in the overall scale and in the sub-dimensions of the sense of meaninglessness, the sense of isolation, selfestrangement, powerlessness and normlessness by the state of the relationship with their managers. The study results of Erjem (2005), Zielinski and Hoy (1983) and Uyar (2007) support the results of this study.

According to the research results, while no significant difference was observed in the alienation of pre-school teachers from the profession by the level of education in the overall scale, and in the sub-dimensions of the sense of meaninglessness, the sense of isolation and powerlessness, a significant difference was determined in the sub-dimensions of self-estrangement and normlessness. According to the studies showing that the levels of alienation of teachers from their profession increase as the level of education increases (Ceylan, 2001; Çalışır, 2006; Gülören, 2011; Haktanır, 2008; Karahan and Ünsar, 2011; Kasapoğlu, 2015; Kesik and Cömert, 2014; Kıłrı, 2013; Kılçık, 2011; Korkmaz, 2014; Mahmutyazıcıŏlu, 2015; Temel, 2010), the perception of powerlessness increases as the educational level of teachers increases.

There are also studies showing that the level of education of teachers does not have an effect on alienation. No difference was found between the level of education and alienation in the studies of Oruç (2004) and Parsak (2010) on university employees, in the study of Kılçık (2011) on teachers working in Malatya province, and in the studies of Eryılmaz (2010), Emir (2012) and Açıkel (2013). 


\section{Giriş}

Yabancılaşma kavramı Latince "alienare" kökünden türetilmiş olup bir şeyin yerini değiştirme, diğerinin yerine koyma ve uzaklaştırma anlamına gelmektedir. Yabancılaşma günlük kullanımda çevreden ya da eski arkadaşlardan uzaklaşma anlamında kullanılmakta iken; sosyoloji ve psikolojide kişinin yaşadığı toplumda kendi kendisine ya da diğer insanlara aşırı derecede hissettiği yabancılık durumunu anlatmak için kullanılmaktadır (Kızılçelik ve Erjem, 1992). Halaçoğlu (2008) sosyolojide yabancılaşmanın dört temel kullanımından söz ederek bunları; bireylerarası yabancılaşma, sosyo-kültürel yabancılaşma, iş hayatında yabancılaşma ve politik-ekonomik yabancılaşma olarak sıralamaktadır.

Yabancılaşma; Marshal (1999)'a göre bireylerin birbirlerinden ya da belirli bir ortam veya süreçten uzaklaşmaları, Horowitz (1966)'e göre ise dünyaya âit şeylerden, insanlardan ve diğer insanlar tarafından idare edilen dünyaya âit fikirlerden yoğun bir şekilde uzaklaşma olarak ifade edilebilir. Yabancılaşmanın bireyin, diğer insanlara ve topluma karşı duyduğu güvensizlik, mutlu olabileceği yolundaki bütün düşlerinin dağıldığı bir kötümserlik, modern toplum içinde hissettiği güçsüzlük ve ayrıca benzer konumdaki diğer insanlar arasında bulunmanın verdiği korku (Keniston, 1972, akt; Elma, 2003) olarak tanımlandığı da görülmektedir.

Yabancılaşma beş temel boyutta sınıflandırılmıştır. Bunlar anlamsızlık, güçsüzlük, normsuzluk, yalıtılmışlık ve kendine yabancılaşmadır. Güçsüzlük; kişinin beklentilerini ve ideallerini kendisinin belirleyememesi veya sonucu değiştirebilmek için elinden hiçbir şey gelmediğini düşünmesidir. Anlamsızlık; kişinin yaşadığı problemlerle baş edebilme ve onları anlama bilgisinden mahrum olduğunu hissetmesi ve neye, hangi doğruya inanacağını bilememe duygusunu yaşamasıdır. Normsuzluk; belirlenen başarı hedeflerine ulaşabilmek için, toplum tarafindan kabul görmeyen davranışları benimsemesidir. Yalıtılmışlık; bireyin genel anlamda bulunduğu fiziksel çevreden ya da diğer insanlarla ilişkide bulunmaktan kaçınması ya da bu ilişkiyi en aza indirgemesidir. Kendine yabancılaşma; kişinin yaptığı davranışların, geliştirdiği değer ve normların, ihtiyaç ve isteklerine dayanmaması; davranışlarının bunlara uymamasıdır (Seeman, 1959, akt; Elma, 2003).

\section{Eğitimde Yabancılaşma ve Öğretmenlerin İșe Yabancılaşması}

Seeman'a (1967) göre işe yabancılaşma modern-endüstriyel 
toplumların hayat şartlarında tipik bir durumdur. $\mathrm{Bu}$ toplumlarda yabancılaşmış bireylerin sayısının fazla olması nedeniyle yabancılaşmayı bireysel bir olgu olarak değil aynı zamanda toplumsal bir olgu olarak ele almak gerekir. Yabancılaşma işte ve iş dışında kişinin kendi ihtiyaçlarından ve diğer insanlardan uzaklaşma hissini yansıtır (Lang, 1985).

Okullardaki bürokratik yapı, yoğun ve değişken müfredât, hızla değişen teknolojik materyal, kalabalık sınıflar, işlevsiz ve gündelik hayatta işe yaramayacak bilgi yükleri, öğrencilerin ve öğretmenlerin eğitsel karar süreçlerinin dışında tutulması öğretmenlerin işlerine yabancılaşmalarının sebepleri olarak siralanabilir (Erjem, 2005; Sidorkin, 2004; Y1lmaz ve Sarpkaya, 2009).

Öğretmenin işine yabancılaşması hem meslekî çalışmalarını hem de ilişkilerini etkileyerek hayata bakışını, işine yaklaşımını değiştirebilir. Elma'ya (2003) göre öğretmenlerde oluşacak mesleğe yabancılaşma: öğrencilerin başarılarına ve sorunlarına karşı duyarsız kalma, okula ve işe olan bağlılı̆̆ının azalması, öğrencilere yaptığı katkı konusunda kendisini yeterli bulmama, öğrencilerle uğraşmaktan bıkma vb. biçiminde kendini gösterebilir. Aynı zamanda öğretmenin kendini bir "ders verme makinesi" olarak düşünmeye başlaması, öğretme eyleminin anlamsızlaşması ve sanki otomatiğe bağlanmış hissi uyandırması, kendi duygu ve düşüncelerini yeterince aktaramaması biçiminde de ortaya çıkabilir.

Hoşgörür (1997) mesleğe yabancılaşmanın, öğretmenin öğrencilerine ve topluma örnek olmasının, meslekî yönden kendisini geliştirmesinin, toplumsal kalkınmaya katkısının, öğretme-öğrenme sürecindeki etkililiğinin, öğretim hizmetindeki verimliliğinin, okul yönetimi ve diğer öğretmenler ile işbirliği içinde çalışmasını engellediğini ifade etmektedir.

İlgili alanyazın incelendiğinde farklı öğretim kademesindeki öğretmenlerin mesleğe yabancılaşmaları ile ilgili çalışmalar olduğu görülmüştür (Açıkel, 2013; Aslan, 2008; Celep, 2008; Çalışır, 2006; Elma, 2003; Emir, 2012; Erjem, 2005; Gür, 2009; Kesik ve Cömert, 2014; Kılçık, 2011; Kösterelioğlu, 2011; Temel, 2010). Okul öncesi öğretmenlerinin mesleğe yabancılaşmalarıyla ilgili Kıhrı (2013) ve Mahmutyazıcıoğlu'nun (2015) çalışmaları olduğu görülmüştür. Konuyla ilgili çalışmaların sınırlı sayıda olduğu, okul öncesi öğretmenlerinin mesleğe yabancılaşma düzeylerini belirlemek amacıyla yapılan bu çalışmanın okul öncesi öğretmenlerinin ve eğitim kurumlarının gelişmesine katkı sağlayacağı düşünülmektedir. 


\section{Yöntem}

\section{Araştırma Modeli}

$\mathrm{Bu}$ araştırmada nicel araştırma yöntemlerinden betimsel tarama modeli kullanılmıştır. Tarama modeli var olan bir durumu var olduğu şekliyle betimlemeyi amaçlayan araştırma yaklaşımıdır (Karasar, 2009).

\section{Çalışma Grubu}

Araştırmanın çalışma grubunu İstanbul'un Ümraniye ve Küçükçekmece ilçelerindeki 60 resmî ve özel okul öncesi kurumunda çalışan 288 öğretmen oluşturmaktadır. Çalışma grubunun \%98.3'ü kadın, \%1.7’i erkek öğretmendir. Öğretmenlerin \%66.0'1 20-29 yaş grubunda, \%30.2'si 3039 yaş grubunda, \%3.8'i 40-49 yaş grubunda olup; \%46.5'i evli, \%53.4'ü bekardır. Öğretmenlerin \%66.7'si çocuksuz, \%18.1'inin bir çocuğu, $\% 15.3$ 'nün iki çocuğu bulunmaktadır. Hizmet süreleri \%60.8'i 1-5 y1l, \%26.7'si 6-10 y1l, \%8'i 11-15 yıl ve \%4.5'i 16-20 yıl arasındadır.

\section{Veri Toplama Araçları}

Verilerin toplanmasında "Kişisel Bilgi Formu" ve "Okul Öncesi Öğretmenlerinin İşe Yabancılaşma Ölçeği” kullanılmıştır.

Kişisel Bilgi Formu: Araştırmacı tarafından hazırlanan ve okul öncesi eğitim kurumlarında çalışan öğretmenlerin; yaş, cinsiyet, medenî durum, çocuk sayısı, hizmet süresi, çalışma saati, kurum türü, sınıf mevcudu, öğrenim durumu, mezun olunan bölüm, mesleği isteyerek seçme, arkadaş ilişkileri, sınıfında kaynaştırma öğrencisi olup olmaması, kurum imkânları, gelir düzeyi ve yöneticileriyle ilişkileri ile ilgili sorulardan oluşmaktadır.

Okul Öncesi Öğretmenlerinin İşe Yabancılaşma Ölçeği (OIYYÖ): Okul öncesi öğretmenlerinin işe yabancılaşma düzeylerini ölçmek amacıyla Kıhrı (2013) tarafından geliştirilmiştir. Ölçek Anlamsızlık Duygusu (Meaninglessness) (4, $10,14,17,19,20,23,26,34,47,49,55,57,58,59,67-16$ madde), Yalıtılmışlık Duygusu (Isolation) $\left(6,8,12,13,15,18^{*}, 21,29,30,32,37,52\right.$, 60, 61, 62, 64, 68-17 madde), Kendine Yabanc1laşma (Self-Estrangement (2, 3, 25, 27, 28, 33, 36, 38*,40, 41, 42*,44, 45, 54, 56, 63-16 madde), Güçsüzlük Duygusu (Powerlessness) (1, 5, 7, 11, 16, 22, 24, 31, 35, 39, 46, 51, 65-13 madde) ve Normsuzluk (Normlessness) $(9,43,48,50,53,66-6$ madde) olmak üzere 5 alt boyut ve 68 maddeden oluşmaktadır. Bazı maddeler tersine puanlanmaktadır. Her faktörün puanı madde toplamlarının madde sayısına bölünmesi ile elde edilmektedir. Puanların artması faktöre ismini veren ilgili 
özelliğin artması şeklinde yorumlanmaktadır. "Okul Öncesi Öğretmenlerinin İşe Yabancılaşma Ölçeği” değerlendirme sorularında beşli likert ölçeği kullanılmıştır. Katılımcılardan her bir maddeyi (5) Kesinlikle Katılıyorum, (4) Katılıyorum, (3) Kararsızım, (2) Katılmıyorum, (1) Kesinlikle Katılmıyorum seçeneklerinden birini kullanarak değerlendirmeleri istenmiştir. Ölçeğin Güvenirlik Katsayıları Faktör. Cronbach's Alfa Anlamsızlık Duygusu (Meaninglessness) .967, Yalıtılmışlık Duygusu (Isolation) .963, Kendine Yabanc1laşma (Self-Estrangement) .912, Güçsüzlük Duygusu (Powerlessness) .915 Normsuzluk (Normlessness) .823 ve ölçek toplamı için .966 'dir.

\section{Veri Analizi}

Araştırmada toplanan verilerin istatistikî çözümleri için SPSS programından yararlanılmıştır. Değişkenlerin normallik dağılımlarına bakılmış ve buna göre OİYÖ genel ve alt boyutlarından aldıkları puanların medenî durum, meslekî kıdem ve eğitim durumu değişkenlerine göre farklılaşıp farklılaşmadığını belirlemek için Kruskal Wallis-H testi, çocuk sâhibi olup olmadığı değişkenine göre farklılaşıp farklılaşmadığını belirlemek için Bağımsız Grup $t$ Testi ve okul türü değişkenine göre farklılaşıp farklılaşmadığını belirlemek için tek yönlü varyans analizi (ANOVA) testi yapılmıştır. Yapılan analizlerin sonuçları değişkenlere göre ayrılarak aşağıda belirtilmiştir.

Araştırmada kullanılan beşli derecelendirme ölçeğine uygun olarak elde edilen ağırlıklı ortalama puanların derecelendirilmesi ve yorumlanması için 4.20-5.00 (çok yüksek); 3.40-4.19 (yüksek); 2.60-3.39 (kısmen yüksek); 1.80-2.59 (düşük); 1.00-1.79 (çok düşük) aralıkları kullanılmıştır. Grup ortalama puanları arasındaki anlamlı farkların test edilmesinde .05 anlamlılık düzeyi esas alınmıştır.

\section{Bulgular}

Araştırmada toplanan verilerin analizi sonucu elde edilen bulgular araştırma problemlerine bağlı olarak aşağıda açıklanmıştır.

Tablo 1'de OIYYÖ geneli ve alt boyut puanlarına âit aritmetik ortalama ve standart sapma değerleri verilmiştir. Tablo 1'de görüleceği gibi OIYYÖ Anlamsızlık Duygusu alt boyutu puanlarının aritmetik ortalaması $\bar{x}=1.99$, standart sapması .577 olarak; Yalıtılmışlık Duygusu alt boyutu puanlarının aritmetik ortalaması $\bar{x}=2.12$ standart sapmas .512 olarak; Kendine 
Yabancılaşma alt boyutu puanlarının aritmetik ortalaması $\bar{x}=2.00$ standart sapmas1 .594 olarak; Güçsüzlük Duygusu alt boyutu puanlarının aritmetik ortalamas1 $\bar{x}=.69$ standart sapmas1 .691 olarak; Normsuzluk alt boyutu puanlarının aritmetik ortalamas $\bar{x}=2.69$ standart sapması .468 olarak; genel puan aritmetik ortalamas1 $\bar{x}=2.27$ standart sapmas1 .454 olarak hesaplanmıştır. Buna göre okul öncesi öğretmenlerinin işe yabancılaşma düzeyleri; genel ortalamaya göre $\bar{x}=2.27$ ile "düşük" düzeyde, Güçsüzlük Duygusu ve Normsuzluk boyutlarının kısmen yüksek Anlamsızlık Duygusu boyutunun ise en düşük düzeyde olduğu belirlenmiştir.

Tablo 1. OIYYÖ Geneli ve Alt Boyut Puanlarına Âit Aritmetik Ortalama ve Standart Sapma Değerleri

\begin{tabular}{lccc}
\hline Alt Boyutlar & $\mathbf{N}$ & $\overline{\boldsymbol{x}}$ & ss \\
\hline Anlamsızlık Duygusu & 288 & 1.99 & .577 \\
Yalıtılmışlık Duygusu & 288 & 2.12 & .512 \\
Kendine Yabancılaşma & 288 & 2.00 & .594 \\
Güçsüzlük Duygusu & 288 & 2.88 & .691 \\
Normsuzluk & 288 & 2.69 & .468 \\
Genel & 288 & 2.27 & .454
\end{tabular}

Tablo 2'de OIYÖ geneli ve alt boyutu puanlarının haftalık çalışma saati değişkenine göre farklılaşıp farklılaşmadığını belirlemek üzere yapılan Bağımsız Grup t-Testi sonuçları verilmiştir.

Tablo 2. OIYYÖ Geneli ve Alt Boyutu Puanlarının Haftalık Çalışma Saati Değişkenine Göre $t$ Testi Sonuçları

\begin{tabular}{|c|c|c|c|c|c|c|c|c|}
\hline \multirow{2}{*}{ Puan } & \multirow{2}{*}{$\begin{array}{l}\text { Çalış̧ma } \\
\text { Saati }\end{array}$} & \multirow{2}{*}{$\mathbf{N}$} & \multirow{2}{*}{$\bar{x}$} & \multirow{2}{*}{ ss } & \multirow{2}{*}{$\mathrm{Sh}_{\bar{x}}$} & \multicolumn{3}{|c|}{$t$ Testi } \\
\hline & & & & & & $t$ & Sd & $p$ \\
\hline \multirow{2}{*}{$\begin{array}{l}\text { Anlamsizlık } \\
\text { Duygusu }\end{array}$} & 20-30 saat & 174 & 2.00 & .570 & .043 & \multirow{2}{*}{.50} & \multirow{2}{*}{286} & \multirow{2}{*}{.617} \\
\hline & $31-40$ saat & 114 & 1.97 & .588 & .055 & & & \\
\hline Yalıtılmışlık & 20-30 saat & 174 & 2.13 & .488 & .037 & \multirow{2}{*}{.46} & \multirow{2}{*}{286} & \multirow{2}{*}{.644} \\
\hline Duygusu & $31-40$ saat & 114 & 2.10 & .548 & .051 & & & \\
\hline Kendine & 20-30 saat & 174 & 2.71 & .448 & .034 & \multirow{2}{*}{.78} & \multirow{2}{*}{286} & \multirow{2}{*}{.435} \\
\hline Yabancılaşma & $31-40$ saat & 114 & 2.66 & .498 & .047 & & & \\
\hline Güçsüzlük & 20-30 saat & 174 & 1.99 & .559 & .042 & \multirow{2}{*}{-.06} & \multirow{2}{*}{286} & \multirow{2}{*}{.951} \\
\hline Duygusu & $31-40$ saat & 114 & 2.00 & .645 & .060 & & & \\
\hline \multirow{2}{*}{ Normsuzluk } & 20-30 saat & 174 & 2.96 & .681 & .052 & \multirow{2}{*}{2.65} & \multirow{2}{*}{286} & \multirow{2}{*}{$.008 *$} \\
\hline & $31-40$ saat & 114 & 2.74 & .688 & .064 & & & \\
\hline \multirow{2}{*}{ Genel } & 20-30 saat & 174 & 2.28 & .430 & .033 & \multirow{2}{*}{.81} & \multirow{2}{*}{286} & \multirow{2}{*}{.421} \\
\hline & $31-40$ saat & 114 & 2.24 & .490 & .046 & & & \\
\hline
\end{tabular}


Tablo 2'ye göre okul öncesi öğretmenlerinin işe yabanc1laşmaları ölçek genelinde $[\mathrm{t}=.81, p>.05]$, Anlamsızlık Duygusu $[\mathrm{t}=.50, p>.05]$, Yalıtılmışlık Duygusu [t=.46, $p>.05]$, Kendine Yabancılaşma [t=.78, $p>.05]$, Güçsüzlük Duygusu [t=-.06, $p>.05]$ alt boyutlarında haftalık çalışma saati değişkenine göre anlamlı bir farklılık belirlenmemiştir. Ölçeğin Normsuzluk alt boyutunda haftalık çalışma saati değişkenine göre anlamlı farklılık saptanmıştır [ $\mathrm{t}=2.65$, $p<.05]$. Buna göre haftalık çalışma saati 20-30 olan katılımcıların aritmetik ortalaması $(\bar{x}=2.96)$, haftalık çalışma saati $31-40$ saat olan katılımcıların aritmetik ortalamasından $(\bar{x}=2.74)$ daha yüksektir. Diğer bir ifade ile çalışma saati daha az olanların Normsuzluk eğiliminin daha yüksek olduğu söylenebilir.

Tablo 3'te OIYÖ geneli ve alt boyutu puanlarının eğitim kurumun türü değişkenine göre farklılaşıp farklılaşmadığını belirlemek üzere yapılan $t$ testi sonuçları verilmiştir.

Tablo 3. OİYÖ Alt Boyutu Puanlarının Eğitim Kurumun Türü Değişkenine Göre t Testi Sonuçları

\begin{tabular}{|c|c|c|c|c|c|c|c|c|}
\hline \multirow{2}{*}{ Puan } & \multirow{2}{*}{$\begin{array}{l}\text { Okul } \\
\text { Türüu }\end{array}$} & \multirow{2}{*}{$\mathbf{N}$} & \multirow{2}{*}{$\bar{x}$} & \multirow{2}{*}{ SS } & \multirow{2}{*}{$\mathrm{Sh}_{\overline{\mathrm{x}}}$} & \multicolumn{3}{|c|}{$t$ Testi } \\
\hline & & & & & & $t$ & Sd & $p$ \\
\hline \multirow{2}{*}{$\begin{array}{l}\text { Anlamsızlık } \\
\text { Duygusu }\end{array}$} & Devlet & 142 & 2.01 & .513 & .043 & \multirow{2}{*}{.63} & \multirow{2}{*}{286} & \multirow{2}{*}{.526} \\
\hline & Özel & 146 & 1.97 & .633 & .052 & & & \\
\hline \multirow{2}{*}{$\begin{array}{l}\text { Yalıtılmışlık } \\
\text { Duygusu }\end{array}$} & Devlet & 142 & 2.17 & .428 & .036 & \multirow{2}{*}{1.82} & \multirow{2}{*}{286} & \multirow{2}{*}{.069} \\
\hline & Özel & 146 & 2.06 & .578 & .048 & & & \\
\hline \multirow{2}{*}{$\begin{array}{l}\text { Kendine } \\
\text { Yabancılaşma }\end{array}$} & Devlet & 142 & 2.79 & .368 & .031 & \multirow{2}{*}{3.79} & \multirow{2}{*}{286} & \multirow{2}{*}{$.000 *$} \\
\hline & Özel & 146 & 2.59 & .530 & .044 & & & \\
\hline \multirow{2}{*}{$\begin{array}{l}\text { Güçsüzlük } \\
\text { Duygusu }\end{array}$} & Devlet & 142 & 1.99 & .482 & .040 & \multirow{2}{*}{-.28} & \multirow{2}{*}{286} & \multirow{2}{*}{.777} \\
\hline & Özel & 146 & 2.01 & .687 & .057 & & & \\
\hline \multirow{2}{*}{ Normsuzluk } & Devlet & 142 & 3.12 & .612 & .051 & \multirow{2}{*}{6.38} & \multirow{2}{*}{286} & \multirow{2}{*}{$.000 *$} \\
\hline & Özel & 146 & 2.64 & .681 & .056 & & & \\
\hline \multirow{2}{*}{ Genel } & Devlet & 142 & 2.33 & .364 & .031 & \multirow{2}{*}{2.35} & \multirow{2}{*}{286} & \multirow{2}{*}{$.019^{*}$} \\
\hline & Özel & 146 & 2.20 & .522 & .043 & & & \\
\hline
\end{tabular}

Tablo 3'e göre okul öncesi öğretmenlerinin işe yabancılaşmaları Anlamsızlık Duygusu [t=.63, $p>.05]$, Yalıtılmışlık Duygusu [t=1.82, $p>.05]$ ve Güçsüzlük Duygusu [t=-.28, $p>.05]$ alt boyutlarında kurum türü değişkenine göre anlamlı bir farklılık saptanmamıştır. Ölçek genelinde $[\mathrm{t}=2.35, p<.05]$ ve Kendine Yabancılaşma [ $\mathrm{t}=3.79, p<.05]$ ile Normsuzluk $[\mathrm{t}=6.38, p<.05]$ alt boyutlarında eğitim kurumunun türü değişkenine göre 
anlamlı farklılık saptanmıştır. Buna göre devlet/resmî okul öncesi kurumlarında çalışan öğretmenlerin işe yabancılaşma aritmetik ortalamaları $(\bar{x}=2.33)$ özel okul öncesi kurumlarda çalışan öğretmenlerden daha yüksektir ( $\bar{x}=2.20)$. Resmî/devlet okul öncesi kurumlarında çalışan katılımcıların Kendine Yabancılaşma aritmetik ortalaması $(\bar{x}=2.79)$ özel okul öncesi kurumlarında çalışanların aritmetik ortalamasından $(\bar{x}=2.59)$ daha yüksektir. Resmî/devlet okul öncesi kurumlarında çalışan katılımcıların Normsuzluk aritmetik ortalaması $(\bar{x}=3.12)$ özel okul öncesi kurumlarında çalışanların aritmetik ortalamasından ( $\bar{x}=2.64)$ daha yüksektir. Devlet/resmî okul öncesi eğitim kurumlarında çalışanların, özel okul öncesi eğitim kurumlarda çalışanlara göre Yabancılaşma, Kendine Yabancılaşma ve Normsuzluk düzeylerinin daha yüksek olduğu tespit edilmiştir.

Tablo 4'te OIYŸ geneli ve alt boyutu puanlarının mesleğin isteyerek seçilip seçilmediği değişkenine göre farklılaşıp farklılaşmadığını belirlemek üzere yapılan Mann Whitney U-Testi sonuçları verilmiştir.

Tablo 4. OIYYÖ Ölçeği Geneli ve Alt Boyutu Puanlarının Mesleğin İsteyerek Seçilip Seçilmediği Değişkenine Göre Mann Whitney U Testi Sonuçları

\begin{tabular}{llcccccc}
\hline \multirow{2}{*}{ Puan } & $\begin{array}{l}\text { Mesleği } \\
\text { İsteyerek } \\
\text { Seçme }\end{array}$ & $\mathbf{N}$ & $\bar{x}$ & $\sum_{\text {sira }}$ & $\mathbf{U}$ & $z$ & $\boldsymbol{p}$ \\
& Evet & 262 & 140.90 & 36915.50 & & & \\
Anlamsızlık & Hayır & 26 & 180.79 & 4700.50 & 2462.50 & -2.33 & $.020^{*}$ \\
Duygusu & Toplam & 288 & & & & & \\
& Evet & 262 & 139.68 & 36595.00 & & & \\
Yalıtılmışlık & Hayır & 26 & 193.12 & 5021.00 & 2142.00 & -3.12 & $.002^{*}$ \\
Duygusu & Toplam & 288 & & & & & \\
\hline \multirow{2}{*}{$\begin{array}{l}\text { Kendine } \\
\text { Yabancılaşma }\end{array}$} & Evet & 262 & 142.85 & 37428.00 & & & \\
& Hayır & 26 & 161.08 & 4188.00 & 2975.00 & -1.07 & .287 \\
& Toplam & 288 & & & & & \\
\hline \multirow{2}{*}{ Güçsüzlük } & Evet & 262 & 141.99 & 37201.50 & & & \\
Duygusu & Hayır & 26 & 169.79 & 4414.50 & 2748.50 & -1.62 & .104 \\
& Toplam & 288 & & & & & \\
\hline \multirow{2}{*}{ Normsuzluk } & Evet & 262 & 141.62 & 37103.50 & & & \\
& Hayır & 26 & 173.56 & 4512.50 & 2650.50 & -1.87 & .061 \\
& Toplam & 288 & & & & & \\
\hline \multirow{2}{*}{ Genel } & Evet & 262 & 140.82 & 36896.00 & & & \\
& Hayır & 26 & 181.54 & 4720.00 & 2443.00 & -2.38 & $.017^{*}$ \\
& Toplam & 288 & & & & & \\
\hline
\end{tabular}


Tablo 4'e göre okul öncesi öğretmenlerinin OİYÖ geneli ve Anlamsızlık Duygusu ve Yalıtılmışlık Duygusu alt boyutundan aldıkları puanlarda gruplar arasındaki fark anlamlı bulunmuştur $(p<.05)$. Buna göre mesleğini isteyerek seçen öğretmenlerin (sıra ort.=140.90) mesleğini istemeden seçen öğretmenlere (sıra ort.=180.79) göre Anlamsızlık Duygusu alt boyutundan daha düşük puan aldıkları görülmektedir. Mesleğini isteyerek seçen öğretmenlerin (sıra ort.=139.68) mesleğini istemeden seçen öğretmenlere $(\bar{x}=193.12)$ göre Yalıtılmışlık Duygusu alt boyutundan daha düşük puan aldıkları görülmektedir.

Mesleğini isteyerek seçen öğretmenlerin (sıra ort.=140.82) mesleğini istemeden seçen öğretmenlere (sıra ort.=181.54) göre ölçek genelinde daha düşük puan aldıkları görülmektedir. Buna göre mesleği isteyerek seçen öğretmenlerin; Yabancılaşma, Anlamsızlık ve Yalıtılmışlık Duygu düzeylerinin, mesleği istemeyerek seçenlere göre daha düşük olduğu belirlenmiştir.

Tablo 5'te OIYYÖ geneli ve alt boyut puanlarının kaynaştırma öğrencisi olup olmaması değişkenine göre farklılaşıp farklılaşmadığını belirlemek üzere yapılan Bağımsız Grup $t$ Testi sonuçları verilmiştir.

Tablo 5. OİYÖ Geneli ve Alt Boyutu Puanlarının Kaynaştırma Öğrencisi Olup Olmaması Değişkenine Göre t Testi Sonuçları

\begin{tabular}{|c|c|c|c|c|c|c|c|c|}
\hline \multirow{2}{*}{ Puan } & \multirow{2}{*}{$\begin{array}{l}\text { Okul } \\
\text { Türü }\end{array}$} & \multirow{2}{*}{$\mathbf{N}$} & \multirow{2}{*}{$\bar{x}$} & \multirow{2}{*}{ SS } & \multirow{2}{*}{$\mathrm{Sh}_{\bar{x}}$} & \multicolumn{3}{|c|}{$t$ Testi } \\
\hline & & & & & & $t$ & Sd & $p$ \\
\hline Anlamsızlık & Var & 124 & 1.98 & .540 & .049 & \multirow{2}{*}{-.166} & \multirow{2}{*}{286} & \multirow{2}{*}{.868} \\
\hline Duygusu & Yok & 164 & 2.00 & .604 & .047 & & & \\
\hline Yalıtılmışlık & Var & 124 & 2.14 & .470 & .042 & \multirow{2}{*}{.707} & \multirow{2}{*}{286} & \multirow{2}{*}{.480} \\
\hline Duygusu & Yok & 164 & 2.10 & .542 & .042 & & & \\
\hline Kendine & Var & 124 & 2.78 & .470 & .042 & \multirow{2}{*}{2.900} & \multirow[b]{2}{*}{286} & \multirow{2}{*}{$.004^{*}$} \\
\hline Yabancılaşma & Yok & 164 & 2.62 & .456 & .036 & & & \\
\hline Güçsüzlük & Var & 124 & 2.03 & .543 & .049 & \multirow{2}{*}{.824} & \multirow{2}{*}{286} & \multirow{2}{*}{.411} \\
\hline Duygusu & Yok & 164 & 1.97 & .630 & .049 & & & \\
\hline \multirow{2}{*}{ Normsuzluk } & Var & 124 & 2.99 & .680 & .061 & \multirow{2}{*}{2.346} & \multirow{2}{*}{286} & \multirow{2}{*}{$.020 *$} \\
\hline & Yok & 164 & 2.79 & 690 & .054 & & & \\
\hline \multirow{2}{*}{ Genel } & Var & 124 & 2.31 & .429 & .039 & \multirow{2}{*}{1.364} & \multirow{2}{*}{286} & \multirow{2}{*}{.174} \\
\hline & Yok & 164 & 2.23 & .472 & .037 & & & \\
\hline
\end{tabular}

Tablo 5'e göre OIYYÖ genelinde [t=1.364, p>.05], Anlamsızlık 
Duygusu [t=-.166, $p>.05]$, Yalıtılmışlık Duygusu [t=.707, $p>.05]$, Güçsüzlük Duygusu [t=.824, $p>.05]$ alt boyutlarında kaynaştırma öğrencisi olup olmamasına göre anlamlı bir farklılık saptanmamıştır. Ölçeğin Kendine Yabancılaşma [ $\mathrm{t}=2.900, p<.05]$ ve Normsuzluk [ $\mathrm{t}=2.346, p<.05]$ alt boyutlarında kaynaştırma öğrencisi olup olmaması değişkenin göre anlamlı farklılık saptanmıştır. Buna göre sınıfında kaynaştırma öğrencisi olan katılımcıların Kendine Yabancılaşma aritmetik ortalaması $(\bar{x}=2.78)$, sınıfında kaynaştırma öğrencisi olmayan katılımcıların aritmetik ortalamasından $(\bar{x}=2.62)$ daha yüksektir. Diğer bir ifade ile sınıfında kaynaştırma öğrenci olan öğretmenlerin kendilerine yabancılaşma düzeyleri daha yüksektir. Benzer şekilde sınıfinda kaynaştırma öğrencisi olan katılımcılar Normsuzluk alt boyutunda aritmetik ortalaması ( $\bar{x}=2.99)$, sınıfında kaynaştırma öğrencisi olmayan katılımcıların aritmetik ortalamasından $(\bar{x}=2.79)$ daha yüksektir. Diğer bir ifade ile sınıfında kaynaştırma öğrenci olan öğretmenlerin Normsuzluk düzeyleri yabancılaşma düzeyleri daha yüksektir.

Tablo 6'da OIYYÖ geneli ve alt boyutları puanlarının yöneticilerle ilişkiler değişkenine göre farklılaşıp farklılaşmadığını belirlemek üzere yapılan Tek Yönlü Varyans Analizi (ANOVA) sonuçlarına yer verilmiştir.

Tablo 6'ya göre katılımcıların OIYŸ genelinden aldıkları puanlarının yöneticilerle ilişkiler değişkenine göre anlamlı bir farklılık gösterip göstermediğini belirlemek amacıyla yapılan ANOVA sonucunda grupların aritmetik ortalamaları arasındaki farklılık anlamlı bulunmuştur. Ölçek genelinde ( $\mathrm{F}=17.765, p<.05)$, Anlamsızlık Duygusu $(\mathrm{F}=12.127 ; p<.05)$, Yalıtılmışlık Duygusu $(\mathrm{F}=16.840, p<.05)$, Kendine Yabancılaşma $(\mathrm{F}=5.836$, $p<.05)$, Güçsüzlük Duygusu $(\mathrm{F}=17.955, p<.05)$ ve Normsuzluk $(\mathrm{F}=13.478$, $p<.05)$ alt boyutlarında yöneticilerle ilişkiler değişkenine göre anlamlı bir farklılık saptanmıştır. 
Kalem Eğitim ve İnsan Bilimleri Dergisi 2018, 8 (2)

Tablo 6. OİYÖ Alt Boyutları Puanlarının Yöneticilerle İlişskiler Değişkenine Göre ANOVA Sonuçları

\begin{tabular}{|c|c|c|c|c|c|c|c|c|c|c|}
\hline \multicolumn{5}{|c|}{$f, \bar{x}$ ve ss Değerleri } & \multicolumn{6}{|c|}{ ANOVA Sonuçları } \\
\hline Puan & $\begin{array}{l}\text { Yöneticilerle } \\
\text { ilişkiler }\end{array}$ & $\mathbf{N}$ & $\bar{x}$ & SS & Var. K. & $K T$ & $S d$ & $K O$ & $F$ & $p$ \\
\hline \multirow{4}{*}{ 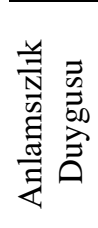 } & Orta & 58 & 2.21 & .686 & G.ArasI & 7.487 & 2 & 3.744 & \multirow{4}{*}{12.127} & \multirow{4}{*}{$.000^{*}$} \\
\hline & İyi & 160 & 2.02 & .512 & G.İ̇ii & 87.981 & 285 & .309 & & \\
\hline & Çok İyi & 70 & 1.74 & .531 & Toplam & 95.468 & 287 & & & \\
\hline & Toplam & 288 & 1.99 & .577 & & & & & & \\
\hline \multirow{4}{*}{ 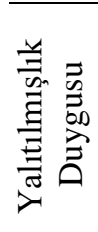 } & Orta & 58 & 2.33 & .634 & G.Arası & 7.941 & 2 & 3.970 & \multirow{4}{*}{16.840} & \multirow{4}{*}{$.000 *$} \\
\hline & İyi & 160 & 2.16 & .454 & G.Ị̇ci & 67.194 & 285 & .236 & & \\
\hline & Çok İyi & 70 & 1.85 & .408 & Toplam & 75.135 & 287 & & & \\
\hline & Toplam & 288 & 2.12 & .512 & & & & & & \\
\hline \multirow{4}{*}{ 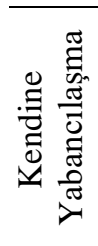 } & Orta & 58 & 2.68 & .585 & G.Arası & 2.473 & 2 & 1.236 & \multirow{4}{*}{5.836} & \multirow{4}{*}{$.003^{*}$} \\
\hline & İyi & 160 & 2.76 & .374 & G.İçi & 60.381 & 285 & .212 & & \\
\hline & Çok İyi & 70 & 2.54 & .520 & Toplam & 62.854 & 287 & & & \\
\hline & Toplam & 288 & 2.69 & .468 & & & & & & \\
\hline \multirow{4}{*}{ 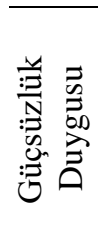 } & Orta & 58 & 2.27 & .714 & G.ArasI & 11.321 & 2 & 5.661 & \multirow{4}{*}{17.955} & \multirow{4}{*}{$.000^{*}$} \\
\hline & İyi & 160 & 2.03 & .505 & G.İçi & 89.852 & 285 & .315 & & \\
\hline & Çok İyi & 70 & 1.69 & .542 & Toplam & 101.173 & 287 & & & \\
\hline & Toplam & 288 & 2.00 & .594 & & & & & & \\
\hline \multirow{4}{*}{ 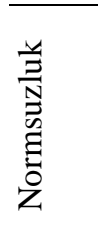 } & Orta & 58 & 3.10 & .752 & G.ArasI & 11.850 & 2 & 5.925 & \multirow{4}{*}{13.478} & \multirow{4}{*}{$.000^{*}$} \\
\hline & İyi & 160 & 2.95 & .632 & G.İçi & 125.288 & 285 & .440 & & \\
\hline & Çok İyi & 70 & 2.53 & .654 & Toplam & 137.139 & 287 & & & \\
\hline & Toplam & 288 & 2.88 & .691 & & & & & & \\
\hline \multirow{4}{*}{$\begin{array}{l}\bar{\Xi} \\
\bar{D} \\
\stackrel{0}{0}\end{array}$} & Orta & 58 & 2.44 & .549 & G.Arası & 6.568 & 2 & 3.284 & \multirow{4}{*}{17.765} & \multirow{4}{*}{$.000 *$} \\
\hline & İyi & 160 & 2.31 & .385 & G.İçi & 52.688 & 285 & .185 & & \\
\hline & Çok İyi & 70 & 2.01 & .416 & Toplam & 59.256 & 287 & & & \\
\hline & Toplam & 288 & 2.27 & .454 & & & & & & \\
\hline
\end{tabular}

$\mathrm{Bu}$ sonucun ardından tamamlayıcı analizlere geçilmiştir. Hangi karşılaştırma analizinin kullanılacağına karar verilirken öncelikle varyansların homojenliği denetlenmiş, varyansların homojen olduğu bulunmuştur $(p>.05)$. 
Farkın hangi gruplar arasında olduğunu belirlemek amacıyla yapılan Scheffe analizi sonucunda; ölçek geneli ile ölçeğin Anlamsızlık Duygusu, Yalıtılmışlık Duygusu ve Normsuzluk alt boyutundan alınan puanlarda yöneticilerle ilişkileri orta ve çok iyi olanlar arasında yöneticilerle ilişkileri orta düzeyde olanlar lehine; yöneticilerle ilişkileri iyi ve çok iyi olanlar arasında yöneticilerle ilişkileri iyi düzeyde olanlar lehine anlamlı farklılık saptanmıştır $(p<.05)$. Kendine Yabancılaşma alt boyutundan alınan puanlarda yöneticilerle ilişkileri iyi ve çok iyi olanlar arasında yöneticilerle ilişkileri iyi düzeyde olanlar lehine anlamlı farklılık saptanmıştır ( $p<.05)$. Güçsüzlük Duygusu alt boyutundan alınan puanlarda yöneticilerle ilişkileri orta ve iyi olanlar arasında yöneticilerle ilişkileri iyi olanlar lehine; orta ve çok iyi olanlar arasında yöneticilerle ilişkileri orta düzeyde olanlar lehine; yöneticilerle ilişkileri iyi ve çok iyi olanlar arasında yöneticilerle ilişkileri iyi düzeyde olanlar lehine anlamlı farklılık saptanmıştır $(p<.05)$.

Tablo 7'de OIYYÖ geneli ve alt boyutları puanlarının öğrenim durumu değişkenine göre farklılaşıp farklılaşmadığını belirlemek üzere yapılan ANOVA sonuçları verilmiştir.

Tablo 7'ye göre okul öncesi öğretmenlerinin işe yabancılaşmaları ölçek genelinde $\left[X^{2}=6.26, p>.05\right]$ ve Anlamsizlik Duygusu $\left[X^{2}=2.67, p>.05\right]$, Yalıtılmışl1k Duygusu $\left[X^{2}=4.83, p>.05\right]$ ve Güçsüzlük Duygusu $\left[X^{2}=2.04\right.$, $\mathrm{P}>.05$ ] alt boyutlarında öğrenim durumu değişkenine göre anlamlı bir farklılık saptanmamıştır. Ölçeğin Kendine Yabancılaşma $\left[X^{2}=11.01, p<.05\right]$ ve Normsuzluk $\left[X^{2}=26.48, p<.05\right]$ alt boyutlarında eğitim düzeyi değişkenine göre anlamlı farklılık saptanmıştır. Kendine Yabancılaşma alt boyutunda farklılıkların tespiti için yapılan $t$ testi sonucunda ön lisans ve lisans mezunları arasında lisans mezunları lehine anlamlı fark saptanmıştır $(\mathrm{t}=-3.498 ; p<.05)$. Bunun yanında yapılan Mann Whitney U-Testi sonucunda ise ön lisans ve yüksek lisans mezunları arasında yüksek lisans mezunları lehine anlamlı fark saptanmıştır ( $\mathrm{U}=643.000 ; p<.05)$. Normsuzluk alt boyutunda farklılıkların tespiti için yapılan $t$ testi sonucunda ön lisans ve lisans mezunları arasında lisans mezunları lehine anlamlı fark saptanmıştır $(\mathrm{t}=-4.482 ; p<.05)$. Bunun yanında yapılan Mann Whitney U-Testi sonucunda ise lise ve lisans mezunları arasında lisans mezunları lehine $(\mathrm{U}=1166.000, p<.05)$; lise ve yüksek lisans mezunları arasında yüksek lisans mezunları lehine (U=157.500, $p<.05)$; ön lisans ve yüksek lisans mezunları arasında yüksek lisans mezunları lehine anlamlı fark belirlenmiştir $(\mathrm{U}=637.000, p<.05)$. 
Kalem Eğitim ve İnsan Bilimleri Dergisi 2018, 8 (2)

Tablo 7. OIYYÖ Geneli ve Alt Boyutları Puanlarının Öğrenim Durumu Değişkenine Göre ANOVA Sonuçları

\begin{tabular}{|c|c|c|c|c|c|c|c|}
\hline Puan & $\begin{array}{l}\text { Öğrenim } \\
\text { Durumu }\end{array}$ & $\mathbf{N}$ & $\overline{\mathrm{X}}$ & $X^{2}$ & Sd & $p$ & $\begin{array}{c}\text { Anlamlı } \\
\text { Fark }\end{array}$ \\
\hline \multirow{5}{*}{$\begin{array}{l}\text { Anlamsizlik } \\
\text { Duygusu }\end{array}$} & Lise & 28 & 143.00 & \multirow{5}{*}{2.67} & \multirow{5}{*}{3} & \multirow{5}{*}{.445} & \multirow{5}{*}{---} \\
\hline & Ön lisans & 103 & 134.84 & & & & \\
\hline & Lisans & 138 & 149.79 & & & & \\
\hline & Lisansüstü & 19 & 160.66 & & & & \\
\hline & Toplam & 288 & & & & & \\
\hline \multirow{5}{*}{$\begin{array}{l}\text { Yalıtılmışlik } \\
\text { Duygusu }\end{array}$} & Lise & 28 & 152.63 & \multirow{5}{*}{4.83} & \multirow{5}{*}{3} & \multirow{5}{*}{.185} & \multirow{5}{*}{--- } \\
\hline & Ön lisans & 103 & 130.28 & & & & \\
\hline & Lisans & 138 & 151.45 & & & & \\
\hline & Lisansüstü & 19 & 159.13 & & & & \\
\hline & Toplam & 288 & & & & & \\
\hline \multirow{5}{*}{$\begin{array}{l}\text { Kendine } \\
\text { Yabancılaşma }\end{array}$} & Lise & 28 & 124.32 & \multirow{5}{*}{11.01} & \multirow{5}{*}{3} & \multirow{5}{*}{$.012 *$} & \multirow{5}{*}{$\begin{array}{l}2-3 \\
2-4\end{array}$} \\
\hline & Ön lisans & 103 & 135.81 & & & & \\
\hline & Lisans & 138 & 156.24 & & & & \\
\hline & Lisansüstü & 19 & 175.53 & & & & \\
\hline & Toplam & 288 & & & & & \\
\hline \multirow{5}{*}{$\begin{array}{l}\text { Güçsüzlük } \\
\text { Duygusu }\end{array}$} & Lise & 28 & 158.61 & \multirow{5}{*}{2.04} & \multirow{5}{*}{3} & \multirow{5}{*}{.564} & \multirow{5}{*}{--- } \\
\hline & Ön lisans & 103 & 136.22 & & & & \\
\hline & Lisans & 138 & 147.79 & & & & \\
\hline & Lisansüstü & 19 & 144.71 & & & & \\
\hline & Toplam & 288 & & & & & \\
\hline \multirow{5}{*}{ Normsuzluk } & Lise & 28 & 109.45 & \multirow{5}{*}{26.48} & \multirow{5}{*}{3} & \multirow{5}{*}{$.000 *$} & \multirow{5}{*}{$\begin{array}{l}1-3 \\
1-4 \\
2-3 \\
2-4\end{array}$} \\
\hline & Ön lisans & 103 & 119.17 & & & & \\
\hline & Lisans & 138 & 167.10 & & & & \\
\hline & Lisansüstü & 19 & 169.29 & & & & \\
\hline & Toplam & 288 & & & & & \\
\hline \multirow{5}{*}{ Genel } & Lise & 28 & 143.45 & \multirow{5}{*}{6.26} & \multirow{5}{*}{3} & \multirow{5}{*}{.100} & \multirow{5}{*}{---} \\
\hline & Ön lisans & 103 & 128.88 & & & & \\
\hline & Lisans & 138 & 153.94 & & & & \\
\hline & Lisansüstü & 19 & 162.16 & & & & \\
\hline & Toplam & 288 & & & & & \\
\hline
\end{tabular}

Tablo 8'de OIYYÖ geneli ve alt boyutları puanlarının mezun olunan alan değişkenine göre farklılaşıp farklılaşmadığını belirlemek üzere yapılan tek yönlü varyans analizi (ANOVA) sonuçları verilmiştir.

Tablo 8. OİYÖ Geneli ve Alt Boyutları Puanlarının Mezun Olunan Alan Değişkenine Göre ANOVA Sonuçları 
Yrd. Doç. Dr. Latife KABAKLI-ÇİMEN

\begin{tabular}{|c|c|c|c|c|c|c|c|}
\hline Puan & $\begin{array}{l}\text { Mezun } \\
\text { Olunan Alan }\end{array}$ & $\mathbf{N}$ & $\bar{X}$ & $X^{2}$ & Sd & $p$ & $\begin{array}{c}\text { Anlamlı } \\
\text { Fark }\end{array}$ \\
\hline \multirow{4}{*}{$\begin{array}{l}\text { Anlamsizlık } \\
\text { Duygusu }\end{array}$} & Okul Öncesi & 142 & 149.98 & \multirow{4}{*}{1.53} & \multirow{4}{*}{2} & \multirow{4}{*}{.465} & \multirow{4}{*}{---} \\
\hline & $\begin{array}{l}\text { Çocuk } \\
\text { Gelişimi }\end{array}$ & 118 & 137.28 & & & & \\
\hline & Diğer & 28 & 147.18 & & & & \\
\hline & Toplam & 288 & & & & & \\
\hline \multirow{4}{*}{$\begin{array}{l}\text { Yalıtılmışlik } \\
\text { Duygusu }\end{array}$} & Okul Öncesi & 142 & 150.30 & \multirow{4}{*}{1.75} & \multirow{4}{*}{2} & \multirow{4}{*}{.417} & \multirow{4}{*}{--- } \\
\hline & $\begin{array}{l}\text { Çocuk } \\
\text { Gelişimi }\end{array}$ & 118 & 136.76 & & & & \\
\hline & Diğer & 28 & 147.71 & & & & \\
\hline & Toplam & 288 & & & & & \\
\hline \multirow{4}{*}{$\begin{array}{l}\text { Kendine } \\
\text { Yabancılaşma }\end{array}$} & Okul Öncesi & 142 & 158.50 & \multirow{4}{*}{7.98} & \multirow{4}{*}{2} & \multirow{4}{*}{$.019 *$} & \multirow{4}{*}{$1-2$} \\
\hline & $\begin{array}{l}\text { Çocuk } \\
\text { Gelişimi }\end{array}$ & 118 & 130.17 & & & & \\
\hline & Diğer & 28 & 133.93 & & & & \\
\hline & Toplam & 288 & & & & & \\
\hline \multirow{4}{*}{$\begin{array}{l}\text { Güçsüzlük } \\
\text { Duygusu }\end{array}$} & Okul Öncesi & 142 & 147.71 & \multirow{4}{*}{1.18} & \multirow{4}{*}{2} & \multirow{4}{*}{.553} & \multirow{4}{*}{--- } \\
\hline & $\begin{array}{l}\text { Çocuk } \\
\text { Gelişimi }\end{array}$ & 118 & 138.44 & & & & \\
\hline & Diğer & 28 & 153.77 & & & & \\
\hline & Toplam & 288 & & & & & \\
\hline \multirow{4}{*}{ Normsuzluk } & Okul Öncesi & 142 & 169.81 & \multirow{4}{*}{26.12} & \multirow{4}{*}{2} & \multirow{4}{*}{$.000 *$} & \multirow{4}{*}{$\begin{array}{l}1-2 \\
1-3\end{array}$} \\
\hline & $\begin{array}{l}\text { Çocuk } \\
\text { Gelişimi }\end{array}$ & 118 & 120.96 & & & & \\
\hline & Diğer & 28 & 135.36 & & & & \\
\hline & Toplam & 288 & & & & & \\
\hline \multirow{4}{*}{ Genel } & Okul Öncesi & 142 & 154.31 & \multirow{4}{*}{4.30} & \multirow{4}{*}{2} & \multirow{4}{*}{.116} & \multirow{4}{*}{--- } \\
\hline & $\begin{array}{l}\text { Çocuk } \\
\text { Gelişimi }\end{array}$ & 118 & 132.80 & & & & \\
\hline & Diğer & 28 & 144.04 & & & & \\
\hline & Toplam & 288 & & & & & \\
\hline
\end{tabular}

Tablo 8'e göre okul öncesi öğretmenlerinin işe yabancılaşmaları ölçek genelinde $\left[X^{2}=6.26, p>.05\right]$ ve anlamsizlık duygusu $\left[X^{2}=2.67, p>.05\right]$, yalıtılmışlık duygusu $\left[X^{2}=4.83, p>.05\right]$ ve güçsüzlük $\left[X^{2}=2.04, p>.05\right]$ alt boyutlarında eğitim düzeyi değişkenine göre anlamlı bir farklılık saptanmamıştır. Ölçeğin kendine yabancılaşma $\left[X^{2}=11.01, p<.05\right]$ ve normsuzluk $\left[X^{2}=26.48, p<.05\right]$ alt boyutlarında eğitim düzeyi değişkenine göre anlamlı farklılık saptanmıştır. Genel olarak eğitim düzeye arttıkça kendine yabancılaşma düzeyinde artış görülürken, sadece ön lisans mezunlarının yüksek lisans mezunlarına nazaran kendine yabancılaşma 
Kalem Eğitim ve İnsan Bilimleri Dergisi 2018, 8 (2)

düzeylerinin anlamlı olarak düşük olduğu saptanmıştır. Genel olarak eğitim düzeye arttıkça normsuzluk düzeyinin arttığı görülmektedir. Lise ve ön lisans mezunlarının lisans ve yüksek lisans mezunlarına göre normsuzluk düzeylerinin anlamlı olarak daha düşük olduğu saptanmıştır.

Tablo 9'da OIYYÖ alt boyutları puanlarının iş yerindeki arkadaşlık ilişkileri değişkenine göre farklılaşıp farklılaşmadığını belirlemek üzere yapılan Kruskal Wallis H-Testi sonuçları verilmiştir.

Tablo 9. OİYÖ Alt Boyutları Puanlarının İş Yerindeki Arkadaşlık İlişkileri Değişkenine Göre Kruskal Wallis H-Testi Sonuçları

\begin{tabular}{|c|c|c|c|c|c|c|c|}
\hline Puan & $\begin{array}{l}\text { Arkadaşlık } \\
\text { İlişkileri }\end{array}$ & $\mathbf{N}$ & $\bar{X}$ & $X^{2}$ & Sd & $p$ & $\begin{array}{c}\text { Anlamlı } \\
\text { Fark }\end{array}$ \\
\hline \multirow{5}{*}{$\begin{array}{l}\text { Anlamsizlık } \\
\text { Duygusu }\end{array}$} & Orta Düzeyde & 26 & 196.65 & \multirow{5}{*}{26.38} & \multirow{5}{*}{2} & \multirow{5}{*}{$.000 *$} & \multirow{5}{*}{$\begin{array}{l}1-2 \\
1-3 \\
2-3\end{array}$} \\
\hline & İyi Düzeyde & 146 & 157.16 & & & & \\
\hline & Çok iyi & 116 & 11688 & & & & \\
\hline & Düzeyde & & 110.00 & & & & \\
\hline & Toplam & 288 & & & & & \\
\hline \multirow{4}{*}{$\begin{array}{l}\text { Yalıtılmışlik } \\
\text { Duygusu }\end{array}$} & Orta Düzeyde & 26 & 201.44 & \multirow{4}{*}{38.14} & \multirow{4}{*}{2} & \multirow{4}{*}{$.000 *$} & \multirow{4}{*}{$\begin{array}{l}1-2 \\
1-3 \\
2-3\end{array}$} \\
\hline & İyi Düzeyde & 146 & 161.65 & & & & \\
\hline & Çok iyi & 116 & 110.16 & & & & \\
\hline & Toplam & 288 & & & & & \\
\hline \multirow{4}{*}{$\begin{array}{l}\text { Kendine } \\
\text { Yabancılaşma }\end{array}$} & Orta Düzeyde & 26 & 162.98 & \multirow{4}{*}{2.31} & \multirow{4}{*}{2} & \multirow{4}{*}{.315} & \multirow{4}{*}{--- } \\
\hline & İyi Düzeyde & 146 & 147.01 & & & & \\
\hline & $\begin{array}{l}\text { Çok iyi } \\
\text { Düzeyde }\end{array}$ & 116 & 137.19 & & & & \\
\hline & Toplam & 288 & & & & & \\
\hline \multirow{4}{*}{$\begin{array}{l}\text { Güçsüzlük } \\
\text { Duygusu }\end{array}$} & Orta Düzeyde & 26 & 200.29 & \multirow{4}{*}{24.53} & \multirow{4}{*}{2} & \multirow{4}{*}{$.000 *$} & \multirow{4}{*}{$\begin{array}{l}1-2 \\
1-3 \\
2-3\end{array}$} \\
\hline & İyi Düzeyde & 146 & 154.62 & & & & \\
\hline & Çok iyi & 116 & 119.26 & & & & \\
\hline & Toplam & 288 & & & & & \\
\hline \multirow{4}{*}{ Normsuzluk } & Orta Düzeyde & 26 & 183.27 & \multirow{4}{*}{11.66} & \multirow{4}{*}{2} & \multirow{4}{*}{$.005 *$} & \multirow[t]{4}{*}{$1-3$} \\
\hline & İyi Düzeyde & 146 & 151.31 & & & & \\
\hline & Çok iyi & 116 & 127.24 & & & & \\
\hline & Toplam & 288 & & & & & \\
\hline \multirow{5}{*}{ Genel } & Orta Düzeyde & 26 & 199.65 & \multirow{5}{*}{26.19} & \multirow{5}{*}{2} & \multirow{5}{*}{$.000 *$} & \multirow{5}{*}{$\begin{array}{l}1-2 \\
1-3 \\
2-3\end{array}$} \\
\hline & İyi Düzeyde & 146 & 155.97 & & & & \\
\hline & Çok iyi & 116 & 11770 & & & & \\
\hline & Düzeyde & 116 & 117.70 & & & & \\
\hline & Toplam & 288 & & & & & \\
\hline
\end{tabular}

Tablo 9'a göre okul öncesi öğretmenlerinin işe yabancılaşmaları 
kendine yabancılaşma $\left[X^{2}=2.31, p>.05\right]$ alt boyutunda arkadaşlık ilişkileri değişkenine göre anlamlı bir farklılık saptanmamıştır. Bundan farklı olarak, ölçek geneli $\left[X^{2}=26.19, p<.05\right]$ ile Anlamsızlık Duygusu $\left[X^{2}=26.38, p<.05\right]$, Yalıt1lmışl1k Duygusu $\left[X^{2}=38.14, p<.05\right]$, Güçsüzlük Duygusu $\left[X^{2}=24.53\right.$, $p<.05]$ ve Normsuzluk $\left[X^{2}=11.66, p<.05\right]$ alt boyutlarında arkadaşlık ilişkileri değişkenine göre anlamlı farklılık saptanmıştır. Ölçek genelinde farklılıkların tespiti için yapılan t-Testi sonucunda arkadaşlık ilişkileri iyi ve çok iyi olanlar arasında arkadaşlık ilişkileri iyi olanların lehine anlamlı fark saptanmıştır $(\mathrm{t}=4.047, p<.05)$. Bunun yanında yapılan Mann Whitney U-Testi sonucunda ise arkadaşlık ilişkileri orta ve iyi olanlar arasında arkadaşlık ilişkileri orta olanların lehine ( $\mathrm{U}=1271.000, p<.05)$; arkadaşlık ilişkileri orta ve çok iyi olanlar arasında arkadaşl1k ilişkileri orta olanların lehine $(\mathrm{U}=701.000, p<.05)$ anlamlı fark saptanmıştır.

Anlamsızlık Duygusu alt boyutunda farklı1ıkların tespiti için yapılan tTesti sonucunda arkadaşlık ilişkileri iyi ve çok iyi olanlar arasında arkadaşlık ilişkileri iyi olanların lehine anlamlı fark saptanmıştır $(\mathrm{t}=3.991 ; p<.05)$. Bunun yanında yapılan Mann Whitney U-Testi sonucunda ise arkadaşlık ilişkileri orta ve iyi olanlar arasında arkadaşlık ilişkileri orta olanların lehine $(\mathrm{U}=1327.000 ; p<.05)$; arkadaşlık ilişkileri orta ve çok iyi olanlar arasında arkadaşlık ilişkileri orta olanların lehine $(\mathrm{U}=723.000 ; p<.05)$ anlamlı fark saptanmıştır. Yalıtılmışlık Duygusu alt boyutunda farklılıkların tespiti için yapılan t-Testi sonucunda arkadaşlık ilişkileri iyi ve çok iyi olanlar arasında arkadaşlık ilişkileri iyi olanların lehine anlamlı fark saptanmıştır $(\mathrm{t}=5.193$; $p<.05)$. Bunun yanında yapılan Mann Whitney U-Testi sonucunda ise arkadaşlık ilişkileri orta ve iyi olanlar arasında arkadaşlık ilişkileri orta olanların lehine ( $\mathrm{U}=1262.500 ; p<.05)$; arkadaşlık ilişkileri orta ve çok iyi olanlar arasında arkadaşlık ilişkileri orta olanların lehine $(\mathrm{U}=663.000 ; p<.05)$ anlamlı fark saptanmıştır. Güçsüzlük Duygusu alt boyutunda farklılıkların tespiti için yapılan t-Testi sonucunda arkadaşlık ilişkileri iyi ve çok iyi olanlar arasında arkadaşlık ilişkileri iyi olanların lehine anlamlı fark saptanmıştır $(\mathrm{t}=3.700 ; p<.05)$. Bunun yanında yapılan Mann Whitney U-Testi sonucunda ise arkadaşlık ilişkileri orta ve iyi olanlar arasında arkadaşlık ilişkileri orta olanların lehine ( $\mathrm{U}=1263.500, p<.05)$; arkadaşlık ilişkileri orta ve çok iyi olanlar arasında arkadaşlık ilişkileri orta olanların lehine $(\mathrm{U}=692.000, p<.05)$ anlamlı fark saptanmıştır. Normsuzluk alt boyutunda farklılıkların tespiti için yapılan Mann Whitney U testi sonucunda arkadaşlık ilişkileri orta ve çok iyi 
olanlar arasında arkadaşlık ilişkileri orta olanların lehine $(\mathrm{U}=897.000, p<.05)$ anlamlı fark saptanmıştır.

\section{Sonuç ve Tartışma}

Okul öncesi öğretmenlerinin işe yabancılaşma düzeyleri ile bunları etkileyen değişkenleri belirlemek amacıyla yapılan bu araştırmada öğretmenlerinin işe yabancılaşma seviyelerinin genel olarak düşük düzeyde olduğu belirlenmiştir. Bu konuda yapılan birçok çalışma; (Akpolat ve Oğuz, 2015; Aksu ve Güneri, 2011; Aydın, 2015; Büyükyılmaz, 2007; Celep, 2008; Çalışır, 2006; Elma, 2003; Emir, 2012; Erdem, 2014; Erjem, 2005; Ery1lmaz ve Burgaz, 2011; Kılçık, 2011; Kösterelioğlu, 2011; Yılmaz ve Sarpkaya, 2009; Y1ld1z, 2016; Y1ldız, Akgün ve Y1ld1z, 2013; Yorulmaz, Altınkurt ve Yılmaz, 2015; Şimşek, Balay ve Şimşek, 2012; Temel, 2010) öğretmenlerin işe yabancılaşma düzeylerinin düşük olduğunu göstermekte ve bulgularımızı desteklemektedir. Bundan farklı olarak Şimşek, Balay ve Şimşek (2012) ve Şirin'in (2009) araştırmalarında ise öğretmenlerin orta düzeyde mesleğe yabancılaştıkları görülmektedir. Kesik ve Cömert (2014) araştırmasında öğretmenlerin yabancılaşma düzeyinin "hiçbir zaman/çok düşük" olduğu belirlenmiştir. Kıhrı (2013) ve Kurtulmuş ve Yiğit (2016) öğretmenlerin işe yabancılaşma düzeylerinin kısmen yüksek olduğunu belirlemiştir. Araştırmamızın sonuçları bu konu ile ilgili olarak yapılan diğer araştırma sonuçlarıyla birlikte değerlendirdiğinde öğretmenlerin işe yabancılaşma düzeylerinin genel olarak yüksek düzeyde olmadığı görülmektedir. $\mathrm{Bu}$ durumun eğitim kurumları açısından olumlu olduğu söylenebilir.

Araştırma sonuçlarına göre okul öncesi öğretmenleri yabancılaşmanın alt boyutlarında farklı düzeylerde yabancılaşma yaşamaktadır. Anlamsızlık Duygusu, Yalıtılmışlık Duygusu ve Kendine Yabancılaşma boyutları düşük; Güçsüzlük Duygusu ve Normsuzluk alt boyutlarında ise kısmen yüksek olduğu görülmektedir. Buna göre okul öncesi öğretmenlerinin en fazla Güçsüzlük Duygusu ve Normsuzluk en az Anlamsızlık Duygusu boyutunda yabancılaşma yaşadıkları söylenebilir. Bu çalışmada olduğu gibi eğitim örgütlerinde yabancılaşma ile ilgili olarak yapılan araştırmaların birçoğunda işe yabancılaşmanın en yoğun Güçsüzlük Duygusu ve Anlamsızlık Duygusu boyutunda yaşandığı belirlenmiştir. Bu çalışmalar (Akpolat ve Oğuz, 2015; Aydın, 2015; Büyükyılmaz, 2007; Celep, 2008; Çalışır, 2006; Elma 2003; 
Erjem, 2005; Güneri, 2010; Kesik ve Cömert, 2014; Kıhrı, 2013; K1lçık, 2011; Kılıç, 2009; Yıldız, 2016; Yılmaz ve Sarpkaya, 2009; Temel, 2010) bulgularımızla paralellik göstermektedir. Erjem (2005)'e göre Güçsüzlük Duygusu; yönetimin dişında kalma, yönetim süreçleri üzerinde etkili olamayacağı duygusu, moral ve motivasyon düşüklüğüdür. Mau (1992, s.106) da güçsüzlüğü kişinin amaçlarına ulaşmaya yüksek değer verirken bu hedeflere ulaşacağına olan beklentisinin oldukça düşük olması olarak ifade etmektedir.

Isherwood ve Hoy (1973) okullardaki merkezileşme ve hiyerarşik denetim düzeyi artıkça öğretmenlerin güçsüzlük biçimindeki işe yabancılaşma duygularında da artış olduğunu belirlemişlerdir. Okul öncesi öğretmenlerin yaşadığ1 güçsüzlük duygusunun okuldaki karar mekanizmalarında yeterince yer alamamasından ve motivasyon düşüklügünden kaynaklandığ 1 söylenebilir. Öğretmenlerin yeteneklerini kullanamadığını düşünmesi güçsüzlük duygusunu oluşturan önemli bir etkendir (Duygulu, 1999). Bununla birlikte Güçsüzlük Duygusunu yoğun olarak yaşayan kişilerde sosyal yalıtılmışı̆̆ğın ortaya çıkabileceği belirlenmiştir (Simmons, 1966). Seeman'a (1967) göre bireysel katılımın düşük olduğu ve yüksek düzeyde kontrolün olduğu bürokratik örgütlerde, kişilerin güçsüzlük biçimindeki yabancılaşma düzeyleri yüksektir. Okul öncesi öğretmenlerinin Normsuzluk boyutundaki yabancılaşma düzeylerinin kısmen yüksek olduğu söylenebilir. Bu durum okul içinde belirlenmiş davranış kalıplarını reddetme ve öğretmen başarısı için belirlenen kurallara uymama eğilimi gösterme şeklinde açıklanabilir. Araştırmadan elde edilen bir başka önemli bulgu da, öğretmenlerin Anlamsızlık Duygusu ve Kendine Yabancılaşma alt boyutu puan ortalamalarının oldukça düşük olmasıdır. $\mathrm{Bu}$ konuda özellikle öğretmenlerinin yaptıkları işi anlamlı ve değerli bulmaları, sevmeleri oldukça önemli bir faktör olarak değerlendirilebilir.

Araştırma sonuçları okul öncesi öğretmenlerinin haftalık çalışma saatine göre işe yabancılaşma düzeylerinin Normsuzluk alt boyutunda anlamlı farkl11ı gösterdiğini ortaya koymuştur. Haftalık çalışma saati 20-30 olan katılımcıların çalışma süreleri 31-40 saat olan katılımcılara göre daha fazla Normsuzluk yaşadıkları belirlenmiştir. Halaçoğlu (2008) çalışmasında haftalık ders saati 6-10 olan akademisyenlerin haftalık ders saati 21 ve üstü olan akademisyenlere göre daha yüksek düzeyde Güçsüzlük Duygusu boyutunda işe yabancılaşma yaşadıklarını belirlemiştir. Kılıç (2009) 27 
saatten fazla derse giren öğretmenlerdeki Güçsüzlük Duygusu ve Anlamsızlık Duygusu düzeyini daha az derse giren öğretmenlerden daha düşük olduğunu, öğretmenlerin serbest zamanların istendiği gibi kullanılmamasının, güçsüzlüğe bağlı yabancılaşma algısını arttırdığını ifade etmektedir. Ders saatlerinin az olmasından dolayı öğretmenin öğrencilerinde akademik, davranış, tutum vb. noktalarda bir fark oluşturamamasından kaynaklandığ 1 ve bunun sonucunda da işe yabancılaşmaya neden olduğu düşünülmektedir.

Araştırma sonuçlarına göre okul öncesi öğretmenlerinin mesleğe yabancılaşma düzeyleri çalışılan eğitim kurumuna göre anlamlı farklılık göstermektedir. Devlet/resmî okul öncesi eğitim kurumlarında çalışan öğretmenlerinin, özel okul öncesi eğitim kurumlarda çalışanlara göre Kendine Yabancılaşma ve Normsuzluk düzeylerinin daha yüksek olduğu tespit edilmiştir. Kılıç (2009)'a göre devlet liselerinde çalışan öğretmenlerin yabancılaşma düzeyleri özel liselerde çalı̧̧an öğretmenlere göre daha yüksektir. Eryılmaz (2010) devlet ortaöğretim okullarında görev yapan öğretmenlerin özel ortaöğretim okullarındakilere göre daha fazla örgütsel yabancılaşma yaşadıklarını belirlemiştir. Kınık (2010) genel lise öğretmenlerinin Anadolu meslek lisesi öğretmenlerinden daha yüksek düzeyde Normsuzluk yaşadıkları sonucuna ulaşmıştır. Eryılmaz ve Burgaz (2011)'ın çalışmasında Normsuzluk, Güçsüzlük Duygusu ve Kendine Yabancılaşma boyutunda özel lise öğretmenlerinin resmî lise öğretmenlerine göre yabancılaşma düzeyleri daha düşüktür. Açıkel (2013)'e göre devlet okulu öğretmenleri daha yüksek düzeyde Güçsüzlük Duygusu ve Yalıtılmışlık Duygusu yaşamaktadır. Korkmaz (2014) devlet okullarında görev yapan öğretmenlerin özel okullarda görev yapanlara göre daha fazla yabancılaşma algısı yaşadıklarını belirlemiştir. Mahmutyazıcıoğlu (2015) çalışmasında resmî kurumlarda çalışan okul öncesi öğretmenlerinin özel okul öncesi öğretmenlerine göre daha fazla Anlamsızlık Duygusu, Güçsüzlük Duygusu, Normsuzluk ve Yalıtılmışılı Duygusunu yaşadıklarını belirlemiştir. Bütün bu bulgular çalışmamızı desteklemektedir.

Resmî anaokullarındaki öğretmenlerin bu boyutlardaki yabancılaşma düzeylerinin daha yüksek olmasının sebepleri arasında öğretmenlerin sâhip olduğu olumsuz şartlar; ağır ders yükü, materyal eksikliği, yönetsel sorunlar, sıkı müfredat, öğrenci sayılarının fazla öğretmen sayılarının yetersiz olması ve öğretmenlerin çalışmak istediği okulu seçme imkânlarının kısıtlı olması yabancılaşma yaşamalarına sebep olduğu söylenebilir. Buna karşılık özel 
okulların sâhip olduğu fizikî ve maddî imkânlar çerçevesinde eğitim ve öğretim etkinliklerinde daha verimli çalışma firsatı sunması, bürokrasinin daha az olması, öğretmenlerin çalıştıkları okulları kendileri seçebilme fırsatına sâhip olmaları, rekabet ortamının getirdiği canlılık, öğretmenlerin yönetsel işlere yaptıkları katkının daha fazla olması ve okulda düşüncelerinin önemsendiği gibi etkenlerin öğretmenlerin işe yabancılaşmayı daha az yaşamalarına sebep olduğu söylenebilir. Bundan farklı olarak Halaçoğlu (2008) akademisyenlerle yaptığı çalışmada resmî ve özel üniversitede çalışmanın yabancılaşma üzerinde bir farklılık oluşturmadığını belirlemiştir. Kıhrı (2013) çalışmasında kurum türüne göre yabancılaşmanın hiçbir boyutunda anlamlı bir farkl111k belirlememiştir.

Araştırma sonuçlarına göre okul öncesi öğretmenlerinin işe yabancılaşma düzeyleri mesleği isteyerek seçme durumuna göre anlamlı farkl11ık göstermektedir. Mesleği isteyerek seçen okul öncesi öğretmenlerinin Yabancılaşma, Anlamsızlık Duygusu ve Yalıtılmışlık Duygusu düzeyinin, mesleği istemeyerek seçenlere göre daha düşük olduğu belirlenmiştir. Kılıç (2009) çalışmasında mesleğini isteyerek seçen öğretmenlerin işe Yabancılaşma ve Güçsüzlük Duygusu düzeylerinin diğer gruplara göre daha düşük olduğunu belirlemiş̧ir. Meslek seçiminde, mesleğin istihdam alanı ve çalışılan örgütün toplum içindeki konumunun dikkate alındığı bilinmektedir. Öğretmenler, eğitim örgütüne önceden oluşturdukları bir algıyla gelmektedir. Dolayısıyla öğretmenlik mesleğini isteyerek seçenlerin ortaya çıkan meslekî problemleri daha başarılı bir şekilde aşmaya çaba harcadıkları söylenebilir.

Araştırma sonuçlarına göre okul öncesi öğretmenlerinin mesleğe yabancılaşma düzeyleri sınıfında kaynaştırma öğrenci olma durumuna göre anlamlı farklılık göstermektedir. Sınıfında kaynaştırma öğrencisi olan öğretmenlerin Kendine Yabancılaşma ve Normsuzluk düzeyleri daha yüksektir. Seeman (1967) kendine yabancılaşmayı; bireyin kendi gerçekliğini kaybetmesi; bireylerin eylemlerinin amacı olarak kişisel doyum sağlamanın geri plana itilmesi, başka kişi ya da kişisel olmayan amaçlar için bireyin kendini araç durumunda algılaması şeklinde açıklamaktadır. Normsuzluk ise bireyin yaşadığı ortamdaki sosyal normlara uymama, sosyal normlara bağlılı̆̆1 terk etme olarak tanımlanmaktadır (Seeman, 1967). Toplumun yapısında meydana gelen değişmelerle birlikte toplumsal değerlerin ve kuralların işlerliğini yitirmesi sonucunda ortaya çıkan kuralsızlık bireyin sosyal çevre ve toplum normlarını tanımaması durumu olarak ifade 
edilmektedir. Sınıfında kaynaştırma öğrencisi olan öğretmenin öğrencileriyle bire bir ilgilenme durumunda olması ve bunun fazla zaman gerektirmesi öğretmende yabancılaşma duygusunun artmasına sebep olduğu söylenebilir.

Araştırma sonuçlarına göre okul öncesi öğretmenlerinin mesleğe yabancılaşma düzeyleri yöneticileriyle ilişki durumuna göre anlamlı farklılık göstermektedir. Okul öncesi öğretmenlerinin yöneticileriyle ilişki durumu ölçek genelinde, Anlamsızlık Duygusu, Yalıtılmışlık Duygusu, Kendine Yabancılaşma, Güçsüzlük Duygusu ve Normsuzluk alt boyutlarında anlamlı bir farkl111k belirlenmiştir. Buna göre yöneticileri ile ilişkileri düşük ve orta düzeyde olan öğretmenlerin, yöneticilerle ilişkileri güçlü olan öğretmenlere nazar daha yüksek düzeyde Anlamsızlık Duygusu, Yalıtılmışlık Duygusu, Güçsüzlük Duygusu ve Normsuzluk içinde olduğu görülmektedir. Yöneticileri ile ilişkileri orta düzeyde olan öğretmenlerin, yöneticilerle ilişkisi güçlü olan öğretmenlere göre daha yüksek düzeyde Kendine Yabancılaşma duygusu içinde olduğu görülmektedir. Yöneticileri ile ilişkileri düşük ve orta düzeyde olan öğretmenlerin, yöneticilerle ilişki güçlü olan öğretmenlere göre daha yüksek düzeyde yabancılaşma duygusu içinde olduğu görülmektedir. Erjem'in (2005) araştırmasında yönetsel süreçlerin dışında kalmanın, katılımı azaltarak öğretmenler arasında "geri çekilmeye" yol açtı̆̆ belirlenmiştir. Zielinski ve Hoy'un (1983) araştırma bulguları da öğretmenlerin yöneticilerden ve çalışma arkadaşlarından kendilerini soyutlamaları sonucunda, çaresizlik ve işe yaramazlık duygusu yaşadıkları; işe yabancılaşmanın bütün boyutlarından etkilendikleri ortaya çıtı̆̆ görülmektedir. Uyar'ın (2007) araştırmasında, öğretmenler görüş ve önerilerinin okul yönetimince önemsenmesi durumunda, çalışma isteklerinde artış olduğunu, fakat okul yönetimi tarafından görüş ve önerilerinin yeterince önemsenmediğini düşündüklerini ifade etmişlerdir.

Araştırma sonuçlarına göre okul öncesi öğretmenlerinin eğitim düzeyine göre işe yabancılaşmaları ölçek genelinde, Anlamsızlık Duygusu, Yalıtılmışlık Duygusu ve Güçsüzlük Duygusu alt boyutlarında anlamlı bir farklılık göstermezken; Kendine Yabancılaşma ve Normsuzluk boyutlarında anlamlı farklılık belirlenmiştir. Genel olarak eğitim düzeyi arttıkça Kendine Yabancılaşma düzeyinde artış görülürken, ön lisans mezunlarının yüksek lisans mezunlarına göre Kendine Yabancılaşma düzeylerinin anlamlı olarak düşük olduğu görülmüştür. Genel olarak eğitim düzeyi arttıkça Normsuzluk düzeyinin arttığı görülmektedir. Lise ve ön lisans mezunlarının, lisans ve 
yüksek lisans mezunlarına göre Normsuzluk düzeylerinin anlamlı olarak daha düşük olduğu belirlenmiştir. Ceylan (2001) ve Çalışır (2006) ilköğretim okulu öğretmenlerinin Güçsüzlük Duygusu, Anlamsızlık Duygusu, Yalıtılmışlık Duygusu boyutunda, Haktanır (2008) ve Kılçık (2011) ön lisans mezunu öğretmenlerin Güçsüzlük Duygusu düzeyinin diğer öğretmenlerden anlamlı derecede daha düşük olduğunu belirlemiş̧ir. Gülören (2011) ön lisans mezunu teknik öğretmenlerin, lisans mezunu teknik öğretmenlere göre meslekî yabancılaşmalarının daha fazla olduğu sonucuna ulaşmıştır. Temel (2010)'e göre lisans mezunu beden eğitimi öğretmenlerinin meslekî yalıtılmışlık algısı lisansüstü eğitime sâhip beden eğitimi öğretmenlerine göre daha yüksektir. Karahan ve Ünsar (2011), Kıhrı (2013), Kesik ve Cömert (2014), Mahmutyazıcıŏ̆lu (2015) okul öncesi öğretmenlerinin eğitim düzeyi artıkça yabancılaşmayı daha çok yaşadıklarını belirlemişlerdir. Korkmaz (2014)'a göre lisans mezunları yüksek lisans mezunlarına göre kendilerini daha anlamsız, daha güçsüz ve daha yalıtılmış hissetmektedir. Kasapoğlu (2015)'na göre öğretmenlerde eğitim durumu arttıkça güçsüzlük algısı artmaktadır. Öğretmenlerin eğitim düzeyinin işe yabancılaşmada etkili olmadığını ortaya koyan çalışmalar da bulunmaktadır (Açıkel, 2013; Emir, 2012; Eryılmaz, 2010; Kılçık, 2011; Parsak, 2010). Haktanır (2008) çalışmasında ön lisans programına katılan öğretmen adaylarının kişilik özellikleri ile bilgi ve beceri bakımından istenen özelliklere çoğunlukla sâhip olmadıklarını belirlenmiştir. Lisansüstü mezunu öğretmenlerin ön lisans ve lisans mezunu öğretmenlere göre işe yabancılaşma düzeylerinin yüksek oluşunu; öğrenim düzeyi yükselen öğretmenin ideal olanın farkına vararak beklenti düzeyinin artması ile mevcut durumu ile idealize edilen durum arasındaki farkı sorgulama başlamasıyla ortaya çıktığını söyleyebiliriz. Eğer bu öğretmenler kazandıkları bilgileri ve tecrübeleri öğrenme-öğretme ortamlarında aktarma imkânına sâhip olamadıkları hissine kapılırlarsa Anlamsızlık Duygusu yaşayabilir ve kendilerini bu süreçten geri çekebilirler.

Araştırma sonuçlarına göre okul öncesi öğretmenlerinin mesleğe yabancılaşma düzeylerinin mezun olunan lisans programına göre; genel olarak İşe Yabancılaşma, Güçsüzlük Duygusu, Anlamsızlık Duygusu ve Yalıtılmış alt boyutlarında anlamlı bir farklılık olmadığı görülürken, Kendine Yabancılaşma ve Normsuzluk alt boyutunda anlamlı farklılık olduğu belirlenmiştir. Buna göre okul öncesi öğretmenliği mezunlarının, çocuk gelişimi mezunlarına göre Kendine Yabancılaşma ve Normsuzluk 
düzeylerinin anlamlı olarak yüksek olduğu görülmektedir. Şimşek, Balay ve Şimşek (2012) çalışmalarında sınıf öğretmenliği dışındaki lisans programlarından mezun olan öğretmenlerin Normsuzluk boyutunda işe yabancılaşma düzeylerini, sınıf öğretmenlerinden daha yüksek bulmuştur. Öğretmenlerin mesleğe yabancılaşma düzeylerinin branşa göre farklılaştığını (Çevik, 2009; Emir, 2012; Kesik ve Cömert, 2014) gösteren çalışmalar bulunmaktadir.

Araştırma sonuçlarına göre okul öncesi öğretmenlerinin mesleğe yabancılaşma düzeyleri iş yerindeki arkadaş ilişkilerine göre değerlendirildiğinde Kendine Yabancılaşma alt boyutunda anlamlı bir farklılık görülmezken; ölçek geneli ile Anlamsızlık Duygusu, Yalıtılmışlık Duygusu, Güçsüzlük Duygusu ve Normsuzluk alt boyutlarında anlamlı farklılık belirlenmiştir. Buna göre okul öncesi öğretmenlerinin iş arkadaşları ile olan ilişki düzeyi geliştikçe Yabancılaşma, Anlamsızlık Duygusu, Yalıtılmışlık Duygusu, Güçsüzlük Duygusu ve Normsuzluk düzeylerinin anlamlı olarak düştüğü tespit edilmiştir.

\section{Öneriler}

Okul öncesi öğretmenlerinin en fazla Güçsüzlük Duygusu boyutunda yabancılaşma yaşadıkları belirlenmiştir. Okullardaki bürokratik engeller en aza indirilerek, öğretmenlerin potansiyellerini ortaya koyabilecekleri bir ortam sağlanabilir. Öğretmenlere okulları ve kendileriyle ilgili kararlarda söz hakkı tanınarak, işleri üzerinde denetim hakkına sâhip oldukları kanaati oluşturulabilir.

Öğretmenlerin eğitim seviyeleri arttıkça Kendine Yabancılaşma ve Normsuzluk biçimindeki işe yabancılaşma düzeylerinin de arttığı görülmektedir. Lisansüstü eğitim mezunu olan öğretmenlerin beklentilerine uygun eğitim öğretim ortamları sağlanabilir veya eğitim sisteminin farklı kademelerinde görev verilebilir.

Resmî anaokullarında çalışan öğretmenlerin mesleğe yabancılaşma düzeylerinin daha yüksek bulunduğu için resmî anaokullarında açık ve destekleyici bir okul ikliminin oluşturulması, adalet ve eşitlik algılarını zedeleyebilecek her türlü uygulamanın önüne geçilmesi, daha çok yetki kullanımı ve bağımsız çalışma imkânlarının sağlanması önerilebilir.

Öğretmenlerin mesleklerini severek ve isteyerek seçmeleri ve çalışma arkadaşları ve özellikle iyi iletişim ve ilişki içinde olmaları mesleğe 
yabancılaşmayı azaltabilir.

\section{Kaynakça}

Açıkel, S. (2013). Illköğretim öğretmenlerinin örgütsel kültürleri ile işe yabancılaşmaları arasındaki ilişki (İstanbul İli Ataşshir İlçesi Örneği). Yayınlanmamış yüksek lisans tezi, Yeditepe Üniversitesi, Sosyal Bilimler Enstitüsü.

Akpolat, T. ve Oğuz, E. (2015). İlkokul ve ortaokul öğretmenlerinde örgütsel sinizmin işe yabanc1laşma düzeyine etkisi. Mersin Üniversitesi Ĕ̆itim Fakültesi Dergisi, 11(3), 947-971.

Aksu, T. ve Güneri, B. (2011). Öğretim elemanlarının maruz kaldıkları yıldırma davranışlarının işe yabancılaşma üzerine etkisi. $E$ International Journal of Educational Research, 2(4), 28-43.

Aslan, H. (2008). Endüstri meslek liselerinde kültür dersleri ögretmenlerinin mesleğe ve kuruma yabancılaşma düzeyleri. Yayınlanmamış yüksek lisans tezi, Marmara Üniversitesi Fen Bilimleri Enstitüsü.

Aydın, K. (2015). Illkokul ve ortaokul öğretmenlerinin örgütsel adalet algilar ile işe yabancılaşma algıları arasındaki ilişki (Uşak ili örneği). Yayınlanmamış yüksek lisans tezi, Uşak Üniversitesi Sosyal Bilimler Enstitüsü,

Büyükyılmaz, O. (2007). İşletmelerde yabancılaşmanın sosyo-psikolojik etkileri ve Türkiye taşkömürü kurumunda bir uygulama. Yayınlanmamış yüksek lisans tezi, Zonguldak Karaelmas Üniversitesi Sosyal Bilimler Enstitüsü.

Ceylan, D. (2001). Öğretmenlik mesleğinde iş güçlüğ̈̈ ve iş tatminsizliği, http://www.mufettisler.net/makale/is\%20guclugu\%20ve\%20is\%20tat minsizligi.doc

Celep, B. (2008). İlköğretim okulu öğretmenlerinin işe yabancılaşması (Kocaeli ili örneği). Yayınlanmamış yüksek lisans tezi, Kocaeli Üniversitesi Sosyal Bilimler Enstitüsü.

Çalışır, İ. (2006). İlköğretim okulu öğretmenlerinin işe yabancılaşması: Bolu ili örneği. Yayınlanmamış yüksek lisans tezi, Abant İzzet Baysal Üniversitesi Sosyal Bilimler Enstitüsü.

Çevik, R. (2009). Ortaöğretim kurumlarında yönetici davranışlarının 
ögretmenlerin mesleklerine yabancılaşmasına etkisi. Yayınlanmamış yüksek lisans tezi, Yeditepe Üniversitesi Sosyal Bilimler Enstitüsü.

Duygulu, E. (1999). Yabancılaşma olgusuna yönelik karşılaştırmalı bir inceleme. Dokuz Eylül Sosyal Bilimler Dergisi, 1(3), 15-25.

Elma, C. (2003). Illköğretim okulu öğretmenlerinin işe yabancılaşmast. Yayınlanmamış doktora tezi, Ankara Üniversitesi Eğitim Bilimleri Enstitüsü.

Emir, S. (2012). Ortaöğretim öğretmenlerinin yabancılaşma düzeyleri (Aydın ili örneği). Yayınlanmamış yüksek lisans tezi, Adnan Menderes Üniversitesi Sosyal Bilimler Enstitüsü.

Erdem, M. (2014). İş yaşamı kalitesinin işe yabancılaşmayı yordama düzeyi. Kuram ve Uygulamada Eğitim Bilimleri, 14(2), 1-26.

Erjem, Y. (2005). Eğitimde yabancılaşma olgusu ve öğretmen: lise öğretmenleri üzerine sosyolojik bir araştırma. Ĕgitim Bilimleri Dergisi, 3(4), 395-417.

Ery1lmaz, A. (2010). Lise ögretmenlerinin örgütsel yabancılaşma düzeyi. Yayınlanmamış yüksek lisans tezi, Hacettepe Üniversitesi Sosyal Bilimler Enstitüsü.

Eryılmaz, A. ve Burgaz, B. (2011). Özel ve resmi lise öğretmenlerinin örgütsel yabanc1laşma düzeyleri. Eğitim ve Bilim Dergisi, 36(161), 271-286.

Gülören, E. (2011). Teknik öğretmenlerde mesleki yabancılaşma: İzmir örneği. Yayınlanmamış yüksek lisans tezi, Süleyman Demirel Üniversitesi Fen Bilimleri Enstitüsü.

Güneri, B. (2010). Öğretim elemanlarının maruz kaldıkları yıldırma davranışlarının işe yabancılaşmaları üzerine etkisi. Yayınlanmamış yüksek lisans tezi, Akdeniz Üniversitesi Sosyal Bilimler Enstitüsü.

Gür, M. (2009). Meslek liselerinde görev yapan öğretmenlerin okullarındaki güven düzeylerinin işe karşı tutumları ile ilişkisinin araştırılması. Yayınlanmamış yüksek lisans tezi, Yeditepe Üniversitesi Sosyal Bilimler Enstitüsü.

Haktanır, G. (2008). Okul öncesi öğretmeninin niteliği. Ĕgitime Bakış Ĕ̆itimÖğretim ve Bilim Araştırma Dergisi, 4(12), 22-35. 
Halaçoğlu, B. (2008). Üniversitelerdeki akademik personelin mesleki yabancılaşma düzeylerinin çok boyutlu incelenmesi (İstanbul İli Örneği). Yayınlanmamış yüksek lisans tezi, Yeditepe Üniversitesi Sosyal Bilimler Enstitüsü.

Horowitz, I. L. (1966). On alienation and the social order. Philosophy and Phenomenological Research, 27(2), 230-237.

Hoşgörür, V. (1997). Eğitim iş görenlerinin örgütsel tutumları (Samsun İli Ortaögretim Okulları Örneği). Yayınlanmamış doktora tezi, Ankara Üniversitesi Sosyal Bilimler Enstitüsü.

Isherwood, G. B. ve Hoy, W. K. (1973). Bureaucracy, powerlessness and teacher work values. The Journal of Educational Administration, 11(1), 24-138.

Karahan, D. ve Ünsar A. S. (2011). Yabancılaşmanın işten ayrılma eğilimine etkisinin belirlemeye yönelik bir alan araştırması. Süleyman Demirel Üniversitesi İktisadi İdari Bilimler Fakültesi Sosyal ve Elektronik Araştırmalar Dergisi, 15(21), 361- 378.

Karasar, N. (2009). Bilimsel araştırma yöntemi. Ankara: Nobel Yayınc1lık.

Kasapoğlu, S. (2015). İlköğretim okulu öğretmenlerinin işe yabancılaşma düzeyleri ile örgütsel adalet algıları arasındaki ilişki. Yayınlanmamış yüksek lisans tezi, Yıldız Teknik Üniversitesi Sosyal Bilimler Enstitüsü.

Kesik, F. ve Cömert, M. (2014). İlköğretim okullarında görev yapan öğretmenlerin işe yabancılaşma düzeylerine ilişkin algıları (Malatya ili örneği). İnönü Üniversitesi Eğitim Fakültesi Dergisi, 15(1), 27-46.

Kıhr1, G. (2013). Okul öncesi öğretmenleri mesleğe yabancılaşma ölçeğinin geliştirilmesi ve bir örnek uygulama. Yayınlanmamış yüksek lisans tezi, Yeditepe Üniversitesi Sosyal Bilimler Enstitüsü.

Kılçık, F. (2011). İlköğretim okullarında görev yapan ögretmenlerin işe yabancılaşma düzeylerine ilişkin algıları (Malatya İli Örneği). Yayınlanmamış yüksek lisans tezi, İnönü Üniversitesi Eğitim Bilimleri Enstitüsü. 
Kilıç, H. (2009). Sosyo-ekonomik değişkenler açısından eğitimde yabancılaşma olgusu ve öğretmen. Yayınlanmamış yüksek lisans tezi, Mersin Üniversitesi Sosyal Bilimler Enstitüsü.

Kınık, F. Ş. F. (2010). Öğretmenlerin yabancılaşma algıları. Yayımlanmamış yüksek lisans tezi, Yıldız Teknik Üniversitesi Sosyal Bilimler Enstitüsü.

Kızılçelik, S. ve Erjem, Y. (1992). Açıklamalı sosyoloji terimler sözlüğ̈̈. Konya: Göksu Matbaas1.

Korkmaz, H. (2014). Ortaögretim devlet okullarında görev yapan öğretmenlerin yabancılaşma düzeyleri ile örgütsel bağlllıkları arasındaki ilişkinin incelenmesi. Yayınlanmamış yüksek lisans tezi, Bahçeşehir Üniversitesi Eğitim Bilimleri Enstitüsü.

Kösterelioğlu, M. (2011). İlkögrretim okulu ögrretmenlerinin is yasam kalitesi ile işe yabancılaşması arasındaki ilişski. Yayınlanmamış yüksek lisans tezi, Abant İzzet Baysal Üniversitesi Sosyal Bilimler Enstitüsü.

Kurtulmuş, M. ve Yiğit, B. (2016). İşe yabanc1laşmanın öğretmenlerin işten ayrılma niyetine etkisi. Mersin Üniversitesi Eğitim Fakültesi Dergisi, 12(3), 860-871.

Lang, D. (1985). Preconditions of three types of alienation in young managers and professionals. Journal of Occupational Behaviour, 6(3), 171-182. Doi: $10.1002 /$ job.4030060302

Mahmutyazıcıoğlu, L. (2015). Okul öncesi yöneticilerinin algllanan liderlik stilleri ile mesleğe yabancılaşma düzeyi arasındaki ilişkinin incelenmesi (İstanbul İli Anadolu Yakası Örneği). Yayınlanmamış yüksek lisans tezi, Yeditepe Üniversitesi Eğitim Bilimleri Enstitüsü.

Mau, R. Y. (1992). The validity and devolution of a concept: student alienation. Adolescence, 27(107), 731-741.

Marshal, G. (1999). Sosyoloji sözlüğü. (O. Akınhay ve D. Kömürcü, Çev.). Ankara: Bilim Sanat Yayınevi.

Oksay, A. ve Durmaz, M. (2016). Sağlık çalışanlarında yabancılaşma düzeyi Isparta ili örneği. Eskişehir Osmangazi Üniversitesi İIBF Dergisi, 11(2), 269-294. 
Oruç, D. (2004). Kocaeli'ndeki kamu hastanelerinde çalışan hemşirelerdeyabancılaşmayı etkileyen faktörler. Yayınlanmamış yüksek lisans tezi. Kocaeli Üniversitesi Sağlık Bilimleri Enstitüsü.

Parsak, G. (2010). Örgütlerde yabancılaşma ve iş tatmini ilişkisi; Çukurova üniversitesi çalışanları üzerinde bir uygulama. Yayınlanmamış yüksek lisans tezi, Çukurova Üniversitesi Sosyal Bilimler Enstitüsü.

Seeman, M. (1967). On the personel consequences of alienation in work. American Sociological Review, 32(2), 273-285.

Simmons, J. L. (1966). Some intercorrelations among Alienation Measure. Social Forces, 44(3), 370-372.

Sidorkin, A. M. (2004). In the event of learning: Alienation and participative thinking in education. Educational Theory, 54(3), 251-262.

Şimşek, H., Balay, R. ve Şimşek, A. S. (2012). İlköğretim sınıf öğretmenlerinde mesleki yabanc1laşma. Eğitim Bilimleri Araştırmaları Dergisi, 2(1), 53-72.

Şirin, E. F. (2009). Beden eğitimi öğretmenlerinin işe yabancılaşma düzeylerinin bazı değişkenler açısından incelenmesi. Celal Bayar Üniversitesi Beden Eğitimi ve Spor Bilimleri Dergisi, 4(4), 164-177.

Temel, C. (2010). Beden ĕgitimi öğretmenlerinin işe yabancılaşma düzeylerinin çeşitli değişkenler açısından incelenmesi. Yayınlanmamış doktora tezi, Abant İzzet Baysal Üniversitesi Sosyal Bilimler Enstitüsü.

Uyar, Ş. (2007). Öğretmen ve yöneticilerin görüslerine göre öğretmenlerin okul yönetimine katılmaları. Yayınlanmamış yüksek lisans tezi, Ankara Üniversitesi Eğitim Bilimleri Enstitüsü.

Yıldı, E. (2016). Öğretmenlerin meslek etik ilkelerine uygun davranma algılarının işe yabancılaşma-yaşam doyumu ve bazı değişkenler açısından incelenmesi. Yayınlanmamış yüksek lisans tezi, Ahi Evran Üniversitesi Sosyal Bilimler Enstitüsü.

Yıldız, K., Akgün, N. ve Yıldız, S. (2013). İşe yabancılaşma ile örgütsel sinizm arasındaki ilişki. The Journal of Academic Social Science Studies, 6(6), 1253-1284.

Yılmaz, S. ve Sarpkaya, P. (2009). Eğitim örgütlerinde yabancılaşma ve 
Kalem Eğitim ve İnsan Bilimleri Dergisi 2018, 8 (2)

yönetimi. Uluslararası İnsan Bilimleri Dergisi, 6(2), 314-333.

Yorulmaz, Y. İ., Altınkurt, Y. ve Y1lmaz, K. (2015). The relationship between teachers' occupational professionalism and organizational alienation. Educational Process: International Journal, 4(1-2), 31-44.

Doi: 10.12973/edupij.2015.412.3

Zielinski, A. E. ve Hoy, W. K. (1983). Isolation and alienation in elementary schools. Educational Administration Quarterly, 19(27), 27-45. 